\title{
Project
}

\section{Suing the Police in Federal Court*}

In recent years the number of civil suits filed in federal court under 42 U.S.C. $\$ 1983^{1}$ alleging police misconduct ${ }^{2}$ has increased dramatically. ${ }^{3}$ Section 1983 grants a private right of action to redress violations of constitutional rights committed by a person acting under color of state law. Although there are, in theory, other ways of controlling police misconduct, ${ }^{*}$ the popularity of section 1983 suits suggests that

- This Project was financed with research grants from the Connecticut Bar Foundation and the Police Foundation. The analyses, conclusions, and opinions expressed are those of the authors, not of the grantors, their officers, or directors. The assistance of Professor Stanton Wheeler of the Yale Iaw School and of United States District Judge Jon O. Newman is gratefully acknowledged. Particular thanks are extended to the jurors who completed questionnaires and to the judges, attorneys, and police officials who agreed to be interviewed.

1. The statute, 42 U.S.C. $\$ 1983$ (1976), a portion of the Civil Rights Act of 1871, provides:

Every person who, under color of any statute, ordinance, regulation, custom, or usage, of any State or Territory, subjects, or causes to be subjected, any citizen of the United States or other person within the jurisdiction thereof to the deprivation of any rights, privileges, or immunities secured by the Constitution and laws, shall be liable to the party injured in an action at law, suit in equity, or other proper proceeding for redress.

2. The term "police misconduct" is used to describe all police behavior alleged to violate a citizen's constitutional rights with the exception of wiretapping. Wiretapping is excluded because, unlike other types of police misconduct, it is controlled by federal legislation, which includes a specific statute that establishes a separate civil action for victims of illegal wiretaps. See 18 U.S.C. $\$ 2520$ (1976). The inclusion of wiretapping suits would have added two suits to the number of $\S 1983$ suits in the Project sample. See p. 786 infra.

3. Suits against police officers brought under the civil rights statutes have increased from 2,000 in 1971 to over 6,000 in 1977. Police: Under Fire, Fighting Back, U.S. NEws \& WORLD REPORT, Apr. 3, 1978, at 39 [hereinafter cited as Under Fire]; cf. Shook, Police and the Law, Police CHIEF, May 1978, at 8 (suits increased $400 \%$ in five-year period ending early 1970s). Civil rights actions in gencral have increased from 287 in 1960 to 13,113 in 1977. Compare [1960] Ad. OfF. U.S. CTs. ANn. Rep. 232 with [1977] Ad. OfF. U.S. CTs. ANN. REP. 318. This increase is due partially to the expansion of police misconduct litigation. Newman, Suing the Lawbreakers: Proposals to Strengthen the Section 1983 Damage Remedy for Law Enforcers' Misconduct, 87 YALE L.J. 447, 452 nn.19-21 (1978).

4. Other legal mechanisms for controlling police misconduct include (I) the exclusionary rule, (2) actions by the internal affairs office of the police department, (3) criminal sanctions, and (4) suits at common law. Of these, only the last resembles $\$ 1983$ in that it compensates the victim for his injury.

The exclusionary rule was designed to remove one incentive for misconduct by barring the use of illegally obtained evidence, Mapp v. Ohio, 367 U.S. 643, 656 (1961), but the deterrent effect of the rule is strongly disputed. Compare Oaks, Studying the Exclusionary Rule in Search and Seizure, 37 U. CHI. L. Rev. 665, 709, 755-56 (1970) (deterrent effect 
they are perceived by the aggrieved individuals as the most effective means of obtaining relief. Nevertheless, serious doubts exist about the efficacy of section 1983 suits against the police. ${ }^{5}$

To be effective, such suits depend upon a hearing before an impartial body with the power to enforce meaningful sanctions against the offending party. This Project ${ }^{6}$ uses field research to provide sup-

questionable based on empirical research; argument for abolishing rule) and Spiotto, The Search and Seizure Problem-Two Approaches: The Canadian Tort Remedy and the U.S. Exclusionary Rule, I J. Police ScI. \& AD. 36, 49 (1973) (deterrent effect not demonstrated by empirical study) with Canon, Is the Exclusionary Rule in Failing Health? Some New Data and a Plea Against a Precipitous Conclusion, 62 KY. L.J. 681, 725-26 (1974) (rule fulfills its purpose). By its own terms the exclusionary rule does not operate unless the police misconduct occurs during the collection of evidence relating to a criminal prosecution, the defendant is prosecuted, and there is some relevant, illegally obtained evidence to suppress. Oaks, supra, at 720-21.

The internal affairs division of a police department, which processes civilian complaints against officers, can also act to control police misconduct. The objectivity of these divisions, however, has been questioned. Id. at 674; Fetherling \& Levett, The Paradox of Policemen Policing Policemen, L.A. Times, Dec. 18, 1977, pt. 8, at 9, col. 1. Some writers maintain that internal affairs divisions may be more concerned with minor police infractions that mar the image of the department than with violations of citizens' constitutional rights. $I d$.

In theory, police misconduct is deterred also by the possibility that an officer may be prosecuted under 18 U.S.C. $\$ 242$ (1976), which imposes criminal sanctions for misconduct analogous to that proscribed in 42 U.S.C. $\$ 1983$ (1976). The standard of proof required in a criminal prosecution, however, is more exacting than that used in civil trials: the jury must be convinced beyond a reasonable doubt that the misconduct occurred and that the defendant specifically intended to deny the victim's constitutional rights. Screws v. United States, 325 U.S. 91, 104 (1945) (plurality opinion); cf. Monroe v. Pape, 365 U.S. 167, 187 (1961), overruled in part, Monell v. Department of Social Servs., 436 U.S. 658 (1978) (specific intent not required for civil liability). Although a particular state may have its own relevant criminal statute, both state and federal criminal provisions are enforced by the district attorney or the United States Attorney. But government prosecutors, who rely on police departments to make arrests and to gather evidence, are reluctant to prosecute officers. Newman, supra note 3, at 449-50; Schwartz, Complaints Against the Police: Experience of the Community Rights Division of the Philadelphia District Attorney's Office, 118 U. PA. L. REv. 1023, 1024-25 (1970).

Finally, police misconduct may be redressed by a suit in state court for such common law torts as false arrest, assault and battery, and trespass. Nevertheless, most police misconduct suits have been brought in federal court under $\$ 1983$ for the following reasons: federal judges are more familiar with claims involving civil rights; federal judges are less sensitive to local political pressures; federal discovery rules are more liberal; and backlogs on federal court dockets are shorter in some jurisdictions. NATIONAL LAwYers Guild, Police Misconduct Litigation Manual 27 (M. Avery \& D. Rudovsky eds. 1978).

5. See Fundt, Suing Municipalities Directly Under the Fourteenth Amendment, 70 Nw. U.L. REv. 770 (1975) (remedy flawed by jury bias, inappropriate defenses, lack of municipal liability, difficulty of obtaining injunctive relief); Newman, supra note 3, at 453 (section 1983 suit is "brought by the wrong plaintiff against the wrong defendant, subject to the wrong defenses, litigated under the wrong burden of proof, and rewarded if successful with the wrong measure of damages"); Note, Damage Remedies Against Municipalities for Constitutional Violations, 89 HARv. L. REv. 922 (1976) (municipal liability necessary to fulfill goals of compensation and deterrence).

6. The "Project" is a research study of some of the $\$ 1983$ suits brought against the police in Connecticut between 1970 and 1977. It is not, however, intended to be a wellcontrolled social scientific experiment. The absence of control groups, a randomly selected 
port for the following propositions: (1) juries, the critical decisionmaking bodies in section 1983 suits, are not impartial because many jurors disfavor plaintiffs and favor police defendants in these suits; and (2) adverse verdicts have minimal effect on defendants because police departments and police officers are insulated from the consequences of the suits.

Jury bias is a critical issue in evaluating the efficacy of the section 1983 action. Jury verdicts not only determine liability of individual defendants, but also establish the standards against which all police misconduct claims are measured. ${ }^{7}$ The possibility that jury bias could frustrate the protection of civil rights was acknowledged as early as the debate over the passage of section $1983 .^{8}$ Recent commentators on police misconduct litigation, moreover, theorize that plaintiffs usually have less jury appeal than police defendants. ${ }^{9}$

The Project focused its research on several factors thought likely to contribute to jury bias. A defendant policeman in a section 1983 action may benefit from the image of authority and respectability evoked by his office, ${ }^{10}$ and the good faith defense ${ }^{11}$ may reinforce biases

sample, and a large sample size limit the statistical tests applicable to the data. Rather, the Project was conceived as an exploratory study, and due attention was given to the need for flexibility as issues of importance became obvious from initial research. To the extent possible in such a study, social scientific procedures were employed to increase the accuracy, reliability, and usefulness of the data. See note 33 infra. This was particularly true during the construction of the various questionnaires and interview schedules.

7. See Annual Chief Justice Earl Warken Conference on Advocacy in the United States, The American Jury System 18-19 (1977) [hereinafter cited as American Jury SYSTEM]; Levett \& Fetherling, Prosecuting a Police Officer Is Fighting City Hall, L.A. Times, Dec. 18,1977 , pt. 8 , at 12 , cols. $3-4$.

8. In debate on the Civil Rights Act of 1871, Congressman Hoar of Massachusetts stated:

If the jurors of South Carolina constantly and as a rule refuse to do justice between man and man where the rights of a particular class of its citizens are concerned, and that State affords by its legislation no remedy, that is as much a denial to that class of citizens of the equal protection of the laws as if the State itself put on its statutebook a statute enacting that no verdict should be rendered in the courts of that State in favor of this class of citizens.

Conc. Globe, 42d Cong., Ist Sess. 334 (1871), cited in Monroe v. Pape, 365 U.S. 167, 177 (1961), overruled in part, Monell v. Department of Social Servs., 436 U.S. 658 (1978).

9. Foote, Tort Remedies for Police Violations of Individual Rights, 39 MinN. L. Rev. 493, 501 (1955); Newman, supra note 3, at 454, 456. Contra, Comment, Monetary Claims Under Section 1983: The Right to Trial by Jury, 8 HARV. C.R.-C.L. L. REv. 613, 627 (1973) (juries capable of rendering fair verdicts in civil rights trials).

10. Bivens v. Six Unknown Named Agents, 403 U.S. 388, $421-22$ (1971) (Burger, C.J., dissenting). Several writers have noted that juries favor policemen in criminal prosecutions for misconduct, simply by virtue of their office. See Levett \& Fetherling, supra note 7, at 12, col. 1; MacPherson, Alabama's 'Watergate', Wash. Post, Apr. 3, 1977, § C, at 5, col. 1.

11. The common law defense of good faith and probable cause was applied to $\S 1983$ suits in Pierson v. Ray, 386 U.S. 547, 557 (1967), when the Supreme Court refused to impose liability on officers for enforcing a statute that they reasonably believed was valid but was later ruled unconstitutional, see id. at 555 ("A policeman's lot is not so unhappy 
in the defendant's favor. ${ }^{12}$ On the other hand, the plaintiff's reputation, if not already sullied by a criminal record, ${ }^{13}$ may be called into question simply because the case arises from a confrontation with the police. ${ }^{14}$ Finally, juries may be prejudiced against some plaintiffs because of their race ${ }^{15}$ or unconventional lifestyles. ${ }^{16}$

The second major focus of the Project was an evaluation of the effect of section 1983 suits on defendants in order to assess whether such suits hold accountable those responsible for acts of misconduct. ${ }^{17}$ In this context, the Project studied the effect that misconduct suits had on individual officers. Particular attention was given to determining whether police officers ${ }^{18}$ bore the costs of attorneys' fees, damage

that he must choose between being charged with dereliction of duty if he does not arrest when he has probable cause, and being mulcted in damages if he does.")

The Second Circuit redefined the good faith defense in Bivens v. Six Unknown Named Agents, 456 F.2d 1339 (2d Cir. 1972), as a defense to a proven violation of a citizen's constitutional right if the defendant reasonably believed in good faith that his actions were constitutional. The Bivens defense has two components: one part subjective and the other objective. First, the officer must prove his subjective belief that his action was lawful. Second, the trier of fact must decide that the officer's belief was reasonable, albeit mistaken. $I d$. at 1348. The significant expansion of the defense was that the police officer might not be liable because he believed he had probable cause even though he lacked probable cause for his actions. National LAwYers Guild, supra note 4, at 60 .

The Bivens definition of the good faith defense is followed by most courts. E.g., Bryan v. Jones, 530 F.2d 1210 (5th Cir. 1976) (en banc); Boscarino v. Nelson, 518 F.2d 879 (7th Cir. 1975).

12. See Theis, "Good Faith" as a Defense to Suits for Police Deprivation of Individual Rights, 59 MrNN. L. REv. 991, 1009-12 (1975) (jurors concentrate on officer's belief that his acts were legal while ignoring question of reasonableness of that belief); Comment, $A c$ countability for Government Misconduct: Limiting Qualified Immunity and the Good Faith Defense, 49 TEMP. L.Q. 938, 951-53 (1976) (objective component of defense frequently ignored).

13. Note, Municipal Immunity in Police Torts, 16 Clev.-MAR. L. REv. 448, 449 (1967) (criminal record, indicative of poor moral character, hinders "claim against a police officer"); Note, supra note 5 , at 926 n.28 (plaintiff's perceived criminality may be factor in jury verdicts).

14. Cf. Newman, supra note 3, at 454 ("Frequently the imbalance of jury appeal is further distorted by the facts of the episode in which the alleged police misconduct occurred."); Note, supra note 13, at 449 ("In many cases the victim possesses a criminal record or was attempting to commit a crime at the time the offense against him took place, items which would decidedly influence the amount of a judgment awarded by a jury, if not the judgment itself.")

15. Note, supra note 5, at 926 n.28. Jury bias may occur not only in police misconduct suits but also in civil rights trials generally. See, e.g., Goldfarb \& Kurzman, Civil Rights v. Civil Liberties: The Jury Trial Issue, 12 U.C.L.A. L. Rev. 486, 487 (1965); Note, Congressional Provision for Nonjury Trial Under the Seventh Amendment, 83 YAl. L.J. 401,401 (1973).

16. Foote, supra note 9, at 499-501; Theis, supra note 12, at 991 . For examples of unconventional lifestyles, see p. 792 infra.

17. Newman, supra note 3, at 447-48, 455-57; see R. Sulnick, Civil Litigation and the Police: A Method of Communication 24 (1976) (empirical research supporting hypothesis that civil suits can affect police behavior).

18. Line officers and supervisory personnel were analyzed separately in order to ascertain if differences existed in their experiences as defendants in $\$ 1983$ actions. In Rizzo v. Goode, 423 U.S. 362 (1976), the Court held that superior officers are liable under $\S 1983$ 
awards, and settlements, or whether they were indemnified for these expenses by their municipal employers or by the municipality's insurance carrier. ${ }^{10}$

The Project also assessed the effect of these suits on the municipalities and their police departments, which were immune from suit under section 1983 at the time the studied cases were brought. ${ }^{20}$ Because police behavior may be influenced by court decrees mandating changes in police procedure, ${ }^{21}$ any use by the courts of such equitable power

only if they participated in, encouraged, or ordered the unconstitutional conduct of lower officials, $i d$. at $373-77$. Rizzo rejected any theory of supervisory liability based on a duty to the public to eliminate future police misconduct. Id. at 376. Similarly, the doctrine of respondeat superior has generally been held inapplicable to $\$ 1983$ suits. E.g., Johnson v. Glick, 481 F.2d 1028 (2d Cir.), cert. denied, 414 U.S. 1033 (1973); Jennings v. Davis, 476 F.2d 1271, 1274-75 (8th Cir. 1973). But sec Hesselgesser v. Reilly, 440 F.2d 901 (9th Cir. 1971) (doctrine available in $\$ 1983$ action if permitted under state law).

19. See Comment, supra note 12, at 971; Levett \& Fetherling, supra note 7, at 12, col. 4. Recent decisions allude to the effects of indemnifying or insuring defendants in the $\$ 1983$ context. See Monell v. Department of Social Servs., 436 U.S. 658, 713 n.9 (1978) (Powell, J., concurring); id. at 717 (Rehnquist, J., dissenting); Turpin v. Mailet, 579 F.2d 152, 168 (2d Cir.), vacated and remanded sub nom. City of W. Haven v. Turpin, 47 U.S.L.W. 3360 (U.S. Nov. 28, 1978) (Oakes, J., concurring).

There are indications that it is becoming increasingly difficult for municipalities to buy liability insurance covering the torts of their police officers, but this phenomenon seems more related to the cost of defending an increasing number of suits, see note 3 supra, than to any drastic increase in the number and amounts of settlements or judgments. Under Fire, supra note 3, at 39-40; O'Donnell, Undercovered Cops: Police Find It Harder or Impossible to Get Any Liability Policies, Wall St. J., Nov. 7, 1977, at 1, col. 1.

20. In Monroe v. Pape, 365 U.S. 167 (1961), overruled in part, Monell v. Department of Social Servs., 436 U.S. 658 (1978), the Court held that municipalities were not "persons" within the meaning of the statute and, therefore, were immune from suit under $\S 1983$, id. at 191. In Monell, the Court overruled Monroe, holding municipalities liable under $\S 1983$ for actions of employees taken pursuant to unconstitutional policies, ordinances, regulations, and customs of the municipality. 436 U.S. 658, 690-91. However, the Court ruled that municipalities are not strictly liable under the doctrine of respondeat superior. Id. at 691 . The Court did not specify what constitutes a showing that the plaintiffs' rights were violated pursuant to a "custom" or "policy"; thus, Monell's actual breadth is ambiguous. Because police officers must have significant discretion in the performance of their duties, much of their behavior is not amenable to control by detailed written regulations or ordinances. For this reason, the interpretation given to the terms, "custom" and "policy," may well determine the impact that Monell will have on police misconduct cases brought under $\$ 1983$.

In another suit, the Second Circuit held that a municipality was liable directly under the Fourteenth Amendment when its policymakers authorized or ratified the unconstitutional acts of its employees. Turpin v. Mailet, 579 F.2d 152, 164 (2d Cir.), vacated and remanded sub nom. City of W. Haven v. Turpin, 47 U.S.L.W. 3360 (U.S. Nov. 28, 1978) (en banc). Turpin alleged that the Board of Police Commissioners had encouraged police officers to harass him because the Board had not disciplined, but rather had promoted, an officer against whom Turpin had won a prior $\$ 1983$ suit. $I d$, at 154-55. The court remanded the case, and permitted Turpin to prove his allegations at trial. $I d$. at 168. On appeal to the Supreme Court, judgment was vacated and the case remanded to the Second Circuit for further consideration in light of Monell. City of W. Haven v. Turpin, 47 U.S.L.W. 3360 (U.S. Nov. 28, 1978).

21. In general, judicial use of equitable relief in misconduct cases has been minimal. In order to affect police department practices by means of court orders, it was necessary 
was analyzed. Furthermore, the Project sought to determine the extent to which the costs of indemnifying individual officers encouraged municipal officials to supervise their police departments more closely. ${ }^{22}$

Data for the Project were compiled from a 149-case sample of Connecticut police misconduct suits filed under section $1983 .{ }^{23}$ Information was gathered from three sources: court records; ${ }^{24}$ personal interviews ${ }^{25}$ with various participants in the studied cases, including

to sue supervisory officials, because municipalities themselves were immune from suits under $\$ 1983$ until Monell v. Department of Social Servs., 436 U.S. 658 (1978). Sucl actions were limited by Rizzo v. Goode, 423 U.S. 362 (1976), in which the Supreme Court reversed the judgment of a court of appeals that had upheld an injunction against the mayor and other supervisory officials in Philadelphia because there was no evidence that they had actually issued an unconstitutional policy or directed lower level officials to act unconstitutionally, $i d$. at 377 . The Court held that no relief could be granted based upon a theory of duty to the public to eliminate future police misconduct. $I d$. at 376 . But cf. Carter v. Carlson, 447 F.2d 358 (D.C. Cir. 1971), rev'd on other grounds sub nom. District of Columbia v. Carter, 409 U.S. 418 (1973) (supervisory liability for negligently failing to train subordinates).

22. Some scholars have suggested that municipal employers are in the best position to reduce police misconduct. See, e.g., Kates \& Kouba, Liability of Public Entities Under Section 1983 of the Civil Rights Act, 45 S. CAL. L. REv. 131, 140-41 (1972) ("[E]ven the bad faith official would respond if the costs were high enough to arouse the ire of his constituency:"); Nahmod, Section 1983 and the "Background" of Tort Liability, 50 IND. L.J. 5,10 n.29 (1974).

23. The sample is composed of all police misconduct suits that were filed (1) between January 1, 1970, and December 31, 1973, in the United States District Court for the District of Connecticut, and (2) between January 1, 1974, and September 1, 1977, in the New Haven Division of that district. These suits have two geographical bases because prior to January 1, 1974, all federal cases filed in Connecticut were docketed in the federal courthouse in New Haven, but since that date only the cases filed in the New Haven Division have been kept there. Cases were selected for inclusion in the sample by examining the case description on the docket shcets for civil actions.

24. Generally, the court record contained the pleadings, motions, briefs, interrogatories, and court orders. Depositions are not part of the public record and were not examined by the Project authors. Trial transcripts were studied but are available only for a few witnesses in a few trials. Information usually available from the court files included a factual description of the incident, the procedural history of the case, some personal characteristics of the parties, and the disposition of the suit. The data from the court records are on file with the Yale Law Journal and subsequent citations refer to these files.

25. Because police misconduct suits are politically sensitive, the interviewees were promised anonymity and the interviews were not tape recorded. Each attorney interview, with one exception, was conducted by two members of the Project. Judges and a magistrate were questioned by three members of the Project. Typical interview procedures called for one member to ask questions while the other noted the answers.

To preserve anonymity, each interviewee is identified by a pseudonym, consisting of an initial and a name. The names were assigned arbitrarily; the initials identify the person's role in the suits. The initial " $P$ " represents plaintiffs" attorneys; " $D$ ", defendants' attorneys; "M", attorneys who in different suits had represented both plaintiffs and defendants; " $\mathrm{J}$ ", judges and the magistrate; and " $\mathrm{O}$ ", police officials. For example, one plaintiff's attorney will be cited as "P. Broadway," and one judge will be cited as "J. Anchor." All interviews were conducted between March 3 and April 6, 1978. Members and Editors of the Yale Law Journal have checked the accuracy of the citations to the interviewees' comments; notes from the interviews, however, cannot be made available to the public. 
forty attorneys, ${ }^{26}$ four federal judges, ${ }^{27}$ one federal magistrate, ${ }^{28}$ and four police officials; ${ }^{29}$ and answers by jurors to a mailed questionnaire. ${ }^{30}$ Of the 163 jurors who deliberated on the trials in the sample, ${ }^{31}$

26. The 40 attorneys interviewed included 15 plaintiffs' attorneys, 21 defendants' attorneys, and 4 attorneys with experience on both sides [hereinafter "mixed attorneys"]. In the Project's sample of $\$ 1983$ suits, 59 attorneys appeared as plaintiffs' counsel, 119 appeared as defendants' counsel, and 6 attorneys had experience on both sides.

Intially, 50 attorneys were selected to be interviewed. In order to interview attorneys with the freshest memories of their cases, the Project attempted to speak to every attorney who had primary responsibility for a case closed between January 1, 1977, and December 31,1977 . Attorneys with relatively more experience in these suits were also sought out: the Project attempted to interview all defendants' attorneys who had handled five or more $\$ 1983$ suits and all plaintiffs' attorneys who had handled two or more $\$ 1983$ suits. Several attorneys were chosen because of their participation in cases that involved particularly noteworthy factual situations, parties, and requested relief.

Thirteen of the 50 attorneys who were to have been included in the study were not interviewed. Six declined because their partners had been interviewed, one attorney had moved and could not be located, and six would not speak with the researchers. Additionally, three plaintiffs' attorneys who were not included in the original 50 were interviewed in order to obtain the viewpoints of more experienced plaintiffs' attorneys. This brought the total number of attorneys interviewed to 40 .

Each attorney was questioned about jury bias, the good faith defense, compensation, damages, settlement figures, and the deterrent effect of the suits. See Appendix 1.

27. Four of the five judges of the United States District Court for the District of Connecticut agreed to be interviewed; they were questioned about discovery, the good faith defense, jury selection, jury bias, damages, reforms, deterrence, and municipal liability under $\S 1983$. No questionnaire form was created for these interviews, but the same list of general topics was discussed with each judge.

28. One of the two magistrates in the District of Connecticut was interviewed concerning the pretrial aspects of $\S 1983$ suits.

29. Three police chiefs and one member of a municipal board of police commissioners were questioned about the departments' administrative procedures for handling civilian complaints and about the impact of the suits on the departments and the individual officers. No questionnaire form was created for these interviews; however, the same list of general topics was discussed with each officer. Three police officials declined to be interviewed.

30. Jurors were contacted only after a waiver of the local rule, D. Cons. R. 12(f), was obtained from a United States District Judge of the District of Connecticut. Rule 12(f) prohibits inquiry into the vote or deliberation of any juror. Even with the waiver, restrictions were placed on the form and dissemination of the questionnaire. The questionnaire's content was limited to what the individual juror thought; no questions were permitted about jury deliberations, votes, or the thoughts or comments of other jurors. The questionnaires were sent under a cover letter from the District Judge and were returned anonymously. Follow-up phone calls to remind the jurors to return the questionnaires were prohibited, but one postcard and one mailgram urging completion of the questionnaire were sent to each juror. All questionnaires were mailed to jurors on February 27, 1978; all completed questionnaires were returned on or before March 31 , 1978. The jurors were asked about the plaintiffs, the defendants, the attorneys, the good faith defense, damages, and various factors that might have influenced their decision. See Appendix 2.

To preserve anonymity, each juror is identified with a number, followed by a citation to the case on which he sat. For example, one juror will be cited as "Juror \#15, in Clemons v. DiLieto, No. 14660 (D. Conn., filed Oct. 6, 1971)." Members and Editors of the Yale Law Journal have checked the accuracy of the citations to the jurors' answers; the completed juror questionnaires, however, cannot be made available to the public.

31. Members of 24 juries, which varied in size from five to nine jurors, were sent questionnaires. There were only 124 individual jurors because 31 jurors $(25 \%)$ sat in more 
seventy completed the questionnaire. ${ }^{32}$ These seventy were representative of all the jurors as to sex and outcome of the trial; however, with respect to age and education the responding group was not optimally representative of all the jurors. ${ }^{33}$ Because the respondents overrepresented college-educated jurors, jury bias was probably stronger, rather than weaker, than indicated by the sample evidence..$^{34}$

\section{Jury Bias in Police Misconduct Trials}

The efficacy of the section 1983 remedy depends upon an adjudication before an impartial jury. Although jury trials constitute fewer than one-third of the closed cases in the sample (see Table 1), it is difficult to overestimate the importance of these cases. Attorneys, when deciding whether to file a suit or when bargaining over a settlement,

than one trial. Each juror was sent a questionnaire for each trial on which he sat and was treated as a different person for each trial on which he sat. Because the questionnaires were required to be returned anonymously, the Project was not able to take into account the number of trials on which a juror sat in assessing his answers; neither could differences in the answers of the same juror regarding different trials be analyzed.

32. In addition to the 70 jurors who completed questionnaires, one juror returned an unanswered questionnaire with a two-page essay on the case. Another juror did not complete a questionnaire but telephoned one of the authors and discussed the case. The responses of these two jurors were quoted like the comments of other jurors, but the responses were not coded as answers to specific questions. Furthermore, eight jurors did not complete the questionnaire because they stated that they could not remember enough about the trial to answer the questions, and six jurors returned blank questionnaires.

Jury trials were held in the years from 1974 to 1977. The completed questionnaires overrepresented the later trials in the sample. Every juror who stated that he lacked memory to answer the questions sat on trials in the first two years. The percentage of completed questionnaires increased each year, from $25 \%$ in 1974 to $55 \%$ in 1977 .

33. Information about the sex, age, and education of the 163 jurors who deliberated on the trials was taken from the court's information sheet on each juror. Seventy percent of the jurors were male, $60 \%$ were between 40 and 60 years old, and over $50 \%$ had no more than a high school education. Jurors who responded to the Project questionnaire stated their sex, age, and educational level. Jurors were also classified according to the outcome of the trial on which they sat. With this information a comparison as to these variables was made between all 163 jurors and those who responded to the questionnaire.

A series of chi-square $\left(\chi^{2}\right)$ tests supported observations that the responding jurors were representative of the total group of deliberating jurors for the variables of sex and outcome of the trial on which they deliberated. More specifically, for the sex of the juror, $\chi^{2}=.31$, $\mathrm{df}=1$, and $\mathrm{p}>.50$ ( $\mathrm{p}$ is a measure of the significance of the relationship; probabilities of .05 and less are considered significant, and would demonstrate a lack of representativeness). For the variable of trial outcome, $\chi^{2}=1.43, \mathrm{df}=2$, and $\mathrm{p}=.50$.

The responding sample of jurors was not, however, optimally representative of the population of deliberating jurors with respect to the variables of age or education. Older and more highly educated jurors showed a greater tendency than others to respond. For age, $\chi^{2}=9.33$, $\mathrm{df}=4$, and $\mathrm{p}=.05$; for education, $\chi^{2}=42.6, \mathrm{df}=5$, and $\mathrm{p}<.005$.

34. Sociological studies have consistently shown that better educated people hold fewer prejudices than others. E.g., S. STouffer, Communism, Conformity, and Civil Liberties 89-108 (1966) (better-educated Americans more tolerant of nonconformists than others); $M$. Tumin, DeSEGREGATION 81, 92 (1958) (advanced education reduced ideological resistance to desegregation). 
naturally look for guidance to the results of past jury trials. ${ }^{35}$ The defendants were successful in twenty of the twenty-eight jury trials in the sample; in cases in which plaintiffs won, the average verdict was $\$ 5723 .^{36}$ Data collected by the Project indicate that the relative infrequency of plaintiffs' verdicts and the low damage awards ${ }^{37}$ are due, at least in part, to the biases of jurors.

35. See AMerican JURY System, supra note 7, at 18-19; Levett \& Fetherling, supra note 7 , at 12 , cols. 3.4.

36. The average award for all jury trials, including plaintiffs' and defendants' verdicts, was \$1484. In comparison, the average payment to the plaintiff in cases that were disposed of before trial, either by stipulated dismissal or by dismissal on motions, was $\$ 3766$. Settlement figures could not be obtained for all settled cases; thus, the \$3766 average is computed on the basis of 32 of the 42 stipulated dismissals in the sample and all of the 16 cases dismissed on motions.

The $\$ 3766$ average is distorted somewhat because two cases, arising from the same set of facts, were settled for an amount approximately three times as great as the next largest settlement. See Court File, Evans v. Salafia, No. 14681 (D. Conn., filed Oct. 21, 1971); Court File, Perkins v. Salafia, No. 14509 (D. Conn., filed July 2, 1971). Without these cases, the average settlement would have been $\$ 1972$.

The two cases arose from a police shooting of two brothers, who, with a third person, were attempting to rob a safe located in a junior high school. According to the grand jury report, the third person was an informer and had aided the police in setting a stakeout for the brothers. The informer had been instructed to wear a conspicuous red cap to distinguish him from the brothers. After the three men entered the school at night, the officers shot and killed the two brothers. The brothers were unarmed and a handgun was planted on them after the shooting. At the coroner's inquest the police officers claimed they fired in self-defense. Approximately one year later, the informer, who had been released soon after the incident, was arrested in another state and told the story. Hartford Courant, Nov. 21, 1970, at 12, col. $1 \& 13$. Subsequently, the officers resigned from the force and admitted that they had planted the handgun; they later were convicted of perjury for making false statements at the coroner's inquest. Court File, Perkins v. Salafia, No. 14509 (D. Conn., filed July 2, 1971).

37. Plaintiffs in police misconduct suits seem less likely than plaintiffs in general to succeed in recovering damages. See JuRY Verdict ReseArGH, Inc., Outstanding Plaintiff Aitorneys, in 6 Personal Injury Valuation Handbooks 3274 (Conn. ed. 1976) (any given plaintiff has $65 \%$ probability of being awarded money by jury if case goes to trial). Because this statistic represents at least some cases in which the defendant did not dispute liability, a better statistic to compare with police misconduct cases might be one limited to trials in which the defendant vigorously opposed the plaintiff's version of the story. Thus, a more relevant statistic is the probability of a verdict for the plaintiff in cases in which two automobiles crashed at an intersection and each driver maintained that the green light was in his favor. See JURY VERDICT RESEARCH, INc., Intersection Collisions, in 3 Personal Injury Valuation Handbooks 18 (Conn. ed. 1978) (plaintiff won $49 \%$ of such cases in 1977) [hereinafter cited as Intersection Collisions]. In contrast, plaintiffs in the Project sample won only $26 \%$ of the cases they took to a jury.

Police misconduct plaintiffs also seem to be disadvantaged in the amount of damages awarded when they do win a case. The average verdict to be expected in Connecticut in 1977, in an automobile crash case in which both parties claimed a green light and the plaintiff suffered a simple concussion (less than $\$ 500$ special damages) and minor injuries, can be derived in the following way. The nationwide average of the plaintiffs' verdicts for cases of this type in 1977 was $\$ 4524$. JURY Verdict RESEARCH, INC., Tables of Verdict Expectancy Values for Concussion, in 1 Personal Injury Valuation HandBooks 1021 (Conn. ed. 1978). This figure is increased by a factor of $20 \%$, i.e., to $\$ 5428$, because verdicts in New Haven, Connecticut, average $20 \%$ higher than verdicts nationwide. JURY Verdict Research, Inc., Connecticut Verdict Survey: Area Verdict Guide, in 1 Personal InjuRY Valuation Handboors 2 (Conn. ed. 1977). Because the plaintiff has a $49 \%$ chance 
Table 1: Outcome ${ }^{38}$

$\begin{array}{lcc} & \begin{array}{c}\text { Open } \\ \text { Cases }\end{array} & \begin{array}{c}\text { Closed } \\ \text { Cases }\end{array} \\ \begin{array}{l}\text { Cases remaining open } \\ \text { Cases dismissed on motions }\end{array} & 59 & \\ \text { Cases with stipulated dismissal } & & 16 \\ \text { Bench trials: } & & 42 \\ \quad \begin{array}{l}\text { Plaintiffs' victory } \\ \text { Defendants' victory }\end{array} & & 1 \\ \text { Jury trials:42 } & & 3 \\ \quad \text { Plaintiffs' victory } & & 7 \\ \quad \text { Defendants' victory } & & 20 \\ \quad \text { Hung jury } & 1 & \\ \text { Total } & 60 & 89\end{array}$

of winning such a verdict, the expected value of such a case is (.49) (\$5428), or about $\$ 2700$. Intersection Collisions, supra, at 18. The police misconduct suits most closely analogous to such a personal injury suit are the excessive force cases. See note 61 infra. Both actions involve easily observable physical injuries. Excessive force awards in the Project sample, including both settled and tried cases, successful and unsuccessful, averaged only $\$ 1150$, even though injuries in the Project cases were often more severe than in the automobile accident cases chosen for comparison.

38. The classification is made based upon the disposition of the last remaining cause of action against the last remaining defendant in each case. Thus, if the chief of police and a line officer were sued, even if the chief were granted a motion of summary judgment, the case would be classified as "jury trial" if the line officer was tried before a jury.

39. "Cases remaining open" consists of those suits that were being litigated and in which no judgment had been entered by February 1, 1978, the date research was completed.

40. "Cases dismissed on motions" includes one summary judgment and one directed verdict; the remaining cases were closed because (I) the plaintiff voluntarily dropped the lawsuit without a settlement, or (2) the defendant prevailed on a motion to dismiss for failure to state a cause of action, for lack of prosecution, or for lack of jurisdiction.

41. "Cases with stipulated dismissals" includes those suits that were settled out of court by mutual accord.

42. Although there were 28 jury trials, questionnaires were mailed to members of only 24 juries. Four of the cases were consolidated for one trial. Since only jurors who sat on trials in the New Haven and Bridgeport Divisions were permitted to be surveyed, the jurors who sat on the two jury trials in the Hartford Division were not sent questionnaires. See Court File, Gonzales v. Ganley, No. 14383 (D. Conn., filed May 4, 1971); Court File, Jones v. City of Hartford, No. 13991 (D. Conn., filed Aug. 24, 1970). One case was tried twice; in the first trial the jury was deadlocked, but on retrial, the defendants won. Only the result of the second trial is included in Table 1 , but members of both juries were mailed questionnaires. See Court File, Clemons v. DiLieto, No. 14660 (D. Conn., filed Oct. 6, 1971).

One case with multiple plaintiffs and multiple defendants resulted in a jury verdict for some of the plaintiffs and for some of the defendants; this case was classified as a plaintiffs' verdict. See Court File, Williams v. Dilieto, No. 15646 (D. Conn., filed Feb. 28, 1973). Another classification problem was the consolidation of four suits for one jury trial, which resulted in plaintiffs' verdicts for three cases and in a defendants' verdict for the fourth case. Court File, Pence v. White, No. 15154 (D. Conn., filed July 5, 1972) (defendants' verdict); Court File, Ramos v. Dilieto, No. 14652 (D. Conn., filed Sept. 30, 1971); Court File, Gray v. Dilieto, No. 14640 (D. Conn., filed Sept. 21, 1971); Court File, Smith v. Dilieto, No. 14624 (D. Conn., filed Sept. 15, 1971). Hence, three of the plaintiffs' verdicts were awarded by one jury. 


\section{A. Biases Against Plaintiffs}

\section{Description of Plaintiffs}

In order to understand why prejudice exists against the plaintiffs who bring section 1983 suits against the police, it is necessary to know the characteristics of the plaintiffs, and the activities underlying their allegations of misconduct. About forty percent of the suits in the sample were brought by nonwhite plaintiffs.

Table 2: Plaintiffs' Race

$\begin{array}{lcc} & \begin{array}{c}\text { Number of } \\ \text { suits }\end{array} & \begin{array}{c}\% \text { of } \\ \text { total suits }\end{array} \\ \text { White } & 75 & 50.3 \\ \text { Black } & 48 & 32.2 \\ \text { Hispanic } & 10 & 6.7 \\ \text { Not available } & 16 & 10.7 \\ \text { Total } & 149 & 99.9\end{array}$

Many, but not all, of the plaintiffs are poor. ${ }^{43}$ Although the court files do not usually contain references to the plaintiffs' income, indications of their financial condition do exist. For example, motions to proceed in forma pauperis were granted in fifteen percent of the sample cases. ${ }^{44}$ Difficulties with the discovery process also highlight the plaintiffs' lack of financial resources. Although both plaintiffs' and defendants' attorneys saw depositions as the best method of discovery, ${ }^{45}$ plaintiffs generally could not afford to take them. ${ }^{46}$

43. One exception was a physician who alleged that he was falsely arrested as he collected signatures for a petition urging the impeachment of President Nixon. Court File, Abramovitz v. Dilieto, No. N-74-248 (D. Conn., filed Oct. 21, 1974). In another case, an inhalation therapist with a $\$ 14,000$-a-year income alleged that he was falsely arrested. Court File, Martin v. Consiglio, No. 14741 (D. Conn., filed Nov. 19, 1971).

44. In at least 22 of the 149 cases, the plaintiffs moved to proceed in forma pauperis. To proceed in forma pauperis, a plaintiff must state in good faith that he cannot afford to pay filing costs without depriving himself of the necessities of life. J. Anchor; see Adkins v. E.I. DuPont de Nemours \& Co., 335 U.S. 331, 339.40 (1948); 28 U.S.G. § 1915 (1976).

45. Attorneys were asked what information could be obtained with depositions that was not available through other means of discovery; 30 of the 40 attorneys responded by noting scveral advantages of depositions relative to other discovery devices. Among the advantages mentioned were the opportunity to question the deponent directly and thus ascertain what type of witness he will make, the ability to ask follow-up questions to evasive answers, and the possibility of using the deposition to impeach the witness at trial. E.g., P. Broadway, P. Davenport.

46. E.g., P. Gypsy, P. Sherman. One attempt to reduce the cost of depositions has been to depose witnesses by tape recorder. The court has allowed such a procedure for indigent defendants. See Court File, Gray v. Dilieto, No. 14640 (D. Conn., filed Sept. 21, 1971). However, the court requires that the taped deposition be transcribed, a process that makes such depositions almost as expensive as regular depositions. P. Broadway. 
An accurate description of these plaintiffs shows not only their race and financial resources, but also that many of the persons who sue the police are perceived as unattractive. ${ }^{4 \tau}$ Many are involved in the drug subculture; ${ }^{48}$ some have been arrested for prostitution; ${ }^{40}$ more than a few have had past brushes with the law; ${ }^{50}$ others are gay. ${ }^{51} \mathrm{~A}$ few can only be described as extraordinary individuals. ${ }^{52}$

The activities that precede a confrontation with the police are diverse. ${ }^{53}$ The majority of these suits are filed as the result of a single confrontation between a citizen and a police officer. Typical of such actions are domestic quarrels to which the police are summoned, ${ }^{5+}$ searches of homes predicated on warrants obtained with falsely sworn affidavits, ${ }^{55}$ and arrests for drunk driving in which excessive force is used by the police. ${ }^{56}$

Some of the suits do not result from an isolated confrontation, but issue instead from a series or group of confrontations with the police arising out of a common incident or set of circumstances. Thus, among the earliest filed cases in the sample are the "Cocaine-Quinine" cases, a series of six suits alleging that numerous people had been arrested on fabricated charges of possessing cocaine. ${ }^{57}$ Four of the shooting cases in

47. D. Delmonico, J. York.

48. E.g., Court File, Burns v. Celentano, No. 15469 (D. Conn., filed Nov. 28, 1972) (plaintiff arrested after heroin found in her apartment); Court File, Cretella v. DiLullo, No. 14891 (D. Conn., filed Feb. 14, 1972) (defendant allegedly supplied plaintiff with narcotics and then forced him to become informer).

49. E.g., Court File, Allen v. Logue, No. N-76-235 (D. Conn., filed July 7, 1976) (action to stop harassment of women with numerous prostitution convictions); Court File, Clinton v. City of West Haven, No. N-76-38 (D. Conn., filed Jan. 23, 1976) (masseuse arrested for prostitution).

50. E.g., D. Dwight (three plaintiffs in consolidated trial had total of 14 felony convictions among them); see p. 798 infra.

51. E.g., Court File, Clifford v. Runlett, No. N-75-226 (D. Conn., filed Sept. 25, 1975) (class action to stop harassment of homosexuals).

52. E.g., Court File, Smith v. DiLieto, No. 14624 (D. Conn., filed Sept. 15, 1971) (man filed suit; at time of trial was in process of changing sex).

53. The descriptions in the following two paragraphs and the notes that accompany them are taken from the complaints.

54. E.g., Court File, Sanders v. Cartocetti, No. N-77-183 (D. Conn., filed Apr. 22, 1977) (wife telephones police after quarrel with husband; police upon arrival beat husband); Court File, Heyward v. LeGrand, No. N-77-172 (D. Conn., filed Apr. 15, 1977) (police summoned to domestic quarrel; beat male).

55. E.g., Court File, Burns v. Celentano, No. 15469 (D. Conn., filed Nov. 28, 1972); Court File, Faiella v. Harvey, No. 15412 (D. Conn., filed Oct. 30, 1972).

56. E.g., Court File, Klymuk v. Pichnarcik, No. N-76-344 (D. Conn., filed Oct. 13, 1976) (plaintiff taken to police station following automobile accident because he had been drinking; at station, was denied medical care and injuries aggravated by beating); Court File, Thornhill v. McAfee, No. 14586 (D. Conn., filed Aug. 24, 1971) (plaintiff beaten at scene of arrest and at hospital in doctors' presence).

57. The cocaine was allegedly purchased by two police informers on the instructions of certain police officers, and then planted on the plaintiffs either by the informers or the officers themselves. Subsequent tests by the Connecticut State Department of Health showed the planted substance to be quinine, not cocaine. The plaintiffs sued for damages 
the sample arose from racially motivated civil disturbances in Hartford, Connecticut. ${ }^{58}$ In another group, a police search for dealers in stolen antiques resulted in three suits filed against the police because the search warrants used were invalid. ${ }^{59}$ Table 3 shows all of the cases in the sample classified according to the basis of the case. ${ }^{60}$

Table 3: Basis of the Case ${ }^{61}$

$\begin{array}{lcc}\begin{array}{c}\text { Number of } \\ \text { suits }\end{array} & \begin{array}{c}\% \text { of } \\ \text { total suits }\end{array} \\ \text { Shooting } & 16 & 10.7 \\ \text { Excessive force } & 24 & 16.1 \\ \text { Excessive force/false arrest } & 38 & 25.5 \\ \text { False arrest } & 32 & 21.5 \\ \text { Illegal search } & 25 & 16.8 \\ \text { Harassment } & 8 & 5.4 \\ \text { Deprivation of First Amendment rights } & 4 & 2.7 \\ \text { Other } & 2 & 1.3 \\ \text { Total } & 149 & 100.0\end{array}$

due to illegal searches and false arrests. Court File, Pence v. White, No. 15154 (D. Conn., filed July 5, 1972); Court File, Torres v. DiLieto, No. 14904 (D. Conn., filed Feb. 18, 1972); Court File, Johnson v. DiLieto, No. 14855 (D. Conn., filed Jan. 24, 1972); Court File, Ramos v. Dilieto, No. 14652 (D. Conn., filed Sept. 30, 1971); Court File, Gray v. Dilieto, No. 14640 (D. Conn., filed Sept. 21, 1971); Court File, Smith v. DiLieto, No. 14624 (D. Conn., filed Sept. 15, 1971). The Torres and Johnson cases were dismissed because the plaintiffs could not be located at the time of the trial. Smith, Gray, and Ramos won, but Pence lost, in a consolidated trial.

58. Court File, Bramlet v. City of Hartford, No. 14551 (D. Conn., filed July 28, 1971); Court File, Gonzales v. Ganley, No. 14383 (D. Conn., filed May 4, 1971); Court File, Jones v. City of Hartford, No. 13991 (D. Conn., filed Aug. 24, 1970); Court File, Rivera v. Sullivan, No. 13931 (D. Conn., filed July 6, 1970). In one case a police officer shot the decedent, who was standing on the street 247 feet away. After the administrator of the estate had rejected a settlement offer of $\$ 45,000$, the jury returned a verdict of no liability. Court File, Gonzales v. Ganley, No. 14383 (D. Conn., filed May 4, 1971) (information about settlement negotiations from attorney interviews).

59. Court File, Clifford v. Town of Madison, No. 15763 (D. Conn., filed May 22, 1973); Court File, Nyholt v. Bell, No. 15302 (D. Conn., filed Sept. 7, 1972); Court File, DelVecchio v. Dana, No. 15198 (D. Conn., filed July 20, 1972). The first two cases were settled before trial; the latter resulted in a plaintiff's verdict at trial.

60. The Project authors summarized the allegations of the complaints as the court files were studied. Then each author read each summary and independently decided the "basis of the case." Following comparisons of results, all discrepancies were eliminated.

The "basis of the case" is defined as the type of misconduct that precipitated the other allegations. For example, a plaintiff may allege that he was falsely arrested, that his body and personal effects were illegally searched, that he was falsely imprisoned as he awaited bail, and that he was maliciously prosecuted at his arraignment. If all police actions subsequent to the arrest adhered to proper police procedure, then the basis of the case is false arrest. If multiple plaintiffs alleged separate incidents of misconduct in a single case, the type of misconduct common to every plaintiff is chosen as the basis of the case. Similarly, if different suits were brought by multiple plaintiffs involved in the same incident, each individual suit is assigned a basis of the case.

61. The categories of misconduct are defined as follows:

a. Shooting is the wounding or killing of a human being with a firearm. Not included is the mere discharge of a weapon.

b. Excessive force means all uses of excessive force except shooting, but does not in- 


\section{Racial Prejudice}

The Project data indicate juror prejudice against nonwhite plaintiffs. The first indication of this prejudice is the difference between the percentage of successful suits brought by white plaintiffs and those brought by black plaintiffs in jury trials. White plaintiffs won three of seven jury trials, or approximately forty-three percent, but black plaintiffs won only three of sixteen trials, or nineteen percent. ${ }^{62}$ The contrast becomes starker if it is noted that two of the three successful black plaintiffs gained their victories in the Cocaine-Quinine trial, a consolidated action tried before a single jury. Two of the police defendants in that case had been dismissed from their jobs prior to the trial as a result of an internal police department investigation into the activities surrounding the incident. ${ }^{63}$

The difference in damage awards between successful white and black plaintiffs further supports the inference that the juries were racially prejudiced. Although the total number of plaintiffs' verdicts was small, the award differential was unmistakable: the average award for the three successful whites was over $\$ 7600$; the average award for the three successful blacks was $\$ 1400.64$ Black plaintiffs, therefore, not only won

clude those cases in which it is impossible to determine whether the basis of the case was excessive force or a false arrest.

c. Excessive force/false arrest cases are those suits in which a plaintiff alleges both brutality and an illegal arrest, and in which the court files do not disclose which improper act occurred first.

d. False arrest is an arrest without probable cause.

e. Illegal search is either a warrantless search without probable cause, or a scarch pursuant to a defective warrant.

f. Harassment is the practice of unjustifiably interfering with or disturbing a plaintiff because of his lifestyle, race, or some other reason.

g. Deprivation of First Amendment rights cases are those in which the plaintiff's freedom of expression, either political or artistic, has been infringed.

h. Other includes two cases that do not fit any of the categories. One plaintiff alleged that he had been enslaved by the police through the use of addictive drugs; the other claimed denial of medical care that resulted in the death of a man soon after he had been taken into police custody.

62. There were 28 cases with jury trials in the sample. Sixteen were brought by black plaintiffs, eight by white plaintiffs (one had a hung jurs), and three by Hispanic plaintiffs. In one jury trial the race of the plaintiff could not be determined from the data. For a discussion of the sample size and statistical validity, see note 6 supra.

63. See note 57 supra (citing cases).

64. One of the seven plaintiffs' verdicts in the sample was won by an Hispanic plaintiff, for $\$ 13,000$, in the Cocaine-Quinine case. Court File, Ramos v. DiLieto, No. 14652 (D. Conn., filed Sept. 30, 1971).

If the number of cases is expanded beyond jury trials won by plaintiffs to include those cases in which there was a jury trial with a defendants' verdict, the average award for white plaintiffs was over $\$ 3250$, for blacks $\$ 262$. Thus, when money was awarded by a jury, white plaintiffs averaged over five times as much as blacks. If the unsuccessful plaintiffs are included, the statistics show that the average black plaintiff received from the jury less than one-twelfth the amount won by the average white.

Including settled cases in the calculus does not significantly alter the conclusions. In all cases-settled, tried, or disposed of by the court in some other manner-the awards or 
less often than whites, but when blacks did win, they were awarded less money.

Several jurors, from different trials, said that racial prejudice was an important factor in their jury's decision, even though no questionnaire item specifically asked about racial prejudice. ${ }^{65}$ One juror expressed sympathy for the police, stating, "I believe police officers have a difficult job working in a minority community they are subject to abuse above and beyond the call of duty. I feel that this played a strong part in our verdict."66 A second juror indicated concern that the racial differences between the jurors and the plaintiff made a fair trial difficult: "[B]eing the only minority on the case $\&$ the rest of the juror being from outside N.H. [New Haven] I found this a problem also." An Another juror, noting that even when a juror recognizes his own biases, he is bound to overcompensate or undercompensate for them, questioned whether it was possible to remain "impartial and logical."08 Finally, one white juror, who said he came "from the ghetto" and "knows" about police misconduct, asserted that two factors decided the case he heard: the plaintiff's "color" (black) and his previous criminal record. As this juror saw it, "[w] hen behind the door [ to the jury room], there is so much prejudice that it is not funny." 69

A number of attorneys also indicated that they felt nonwhite plaintiffs were severely disadvantaged..$^{70}$ One simply stated that whites are more likely to succeed at trial and argued that in one of his cases in which a black plaintiff had won, the damage award was lower than a white would have received. ${ }^{71}$ Another placed great importance on whether the plaintiff was "white and middle class."72 One attorney bluntly asserted that "blacks are in a much worse position."73

settlements received by white plaintiffs averaged $\$ 5565$, by blacks $\$ 440$. If the two largest settlements are omitted, see note 36 supra, the average for whites drops to $\$ 2935$. If, in addition, all cases in which the plaintiff received no money are omitted, the average recovery becomes $\$ 4893$ for whites and $\$ 1246$ for blacks.

65. No questionnaire item specifically asks about the juror's racial prejudice because it was thought that jurors would not be candid regarding their own prejudices; moreover, the restrictions on the juror questionnaire prevented asking jurors about the racial prejudices of their fellow jury members. See note 30 supra.

66. Juror \#107, in Garcia v. Carozza, No. N-74-51 (D. Conn., filed Feb. 27, 1974) (Hispanic plaintiff; defendant's verdict). All juror comments are reported verbatim and with their original spelling and punctuation.

67. Juror identification withheld to protect anonymity.

68. Juror \#15, in Clemons v. DiLieto, No. 14660 (D. Conn., filed Oct. 6, 1971) (black plaintiff; defendant's verdict).

69. Juror \#155, in Gaddy ex rel. Jackson v. Gaglionc, No. N-75-97 (D. Conn., filed Apr. 7, 1975) (black plaintiff; defendant's verdict).

70. Several attorneys stated that the plaintiff's race was one of the most important factors in determining the outcome of these suits. E.g., P. Silliman, D. Delmonico.

71. P. Broadway.

72. P. Rudy.

73. P. Sherman. 


\section{Lifestyle Prejudice}

Many of the plaintiffs who brought police misconduct suits had deviant or unusual lifestyles. The outcomes of the jury trials suggest that the jurors were biased against these plaintiffs. Jury verdicts were awarded to seven plaintiffs. Except for the plaintiffs in the CocaineQuinine cases, ${ }^{74}$ all of the winning plaintiffs were gainfully employed at the time of the alleged misconduct. ${ }^{75}$ Even in the Cocaine-Quinine cases, the lifestyles of the three successful plaintiffs apparently affected the jurors' determination of damages: the two plaintiffs with several felony convictions received substantially less money than the plaintiff whose arrest record was not known by the jury. ${ }^{70}$ In contrast, unsuccessful plaintiffs often, though not always, had characteristics that may have limited their jury appeal. ${ }^{77}$ One was a high school dropout; ${ }^{78}$ others were "long-haired" students who demonstrated against the Vietnam War; ${ }^{79}$ some were alcoholics or heavy drinkers; ${ }^{80}$ another was a member of a motorcycle gang; ${ }^{81}$ and yet another was chronically unemployed. ${ }^{82}$

\section{See pp. $792-94$ supra.}

75. One black plaintiff was an inhalation therapist at Yale-New Haven Hospital who earned approximately $\$ 14,000$ per year. Court File, Martin v. Consiglio, No. 14741 (D. Conn., filed Nov. 19, 1971). A second plaintiff was a white garage mechanic and was married, with two children. Court File, DelVecchio v. Dana, No. 15198 (D. Conn., filed July 20, 1972). The plaintiff who was awarded the largest amount by a jury was a young white male working two jobs as an upholsterer; he had assigned the proceeds of any award to repay the welfare benefits he and his dependents had received while he was disabled from the injuries inflicted by the defendant officer. Court File, Delecke ex rel. Delecke v. Tsolis, No. 15244 (D. Conn., filed Aug. 10, 1972). In a fourth case, the defendants were accused of using excessive force against several student antiwar demonstrators and falsely arresting a newspaper photographer covering the event; although all the student plaintiffs lost, the newspaper photographer was awarded damages for being falsely arrested and having his camera destroyed. Court File, Williams v. Dilieto, No. 15646 (D. Conn., filed Feb. 28, 1973). It should be noted that not all gainfully employed plaintiffs won. See, e.g., Court File, Abramovitz v. DiLieto, No. N-74-248 (D. Conn., filed Oct. 21, 1974).

76. See p. 798 infra.

77. Information on the plaintiffs' lifestyles was gathered from the complaints, from answers to interrogatories, and from attorney interviews. The descriptions compiled were neither complete nor systematic; thus, insufficient data are available to isolate the effect on the jury of any one aspect of a plaintiff's lifestyle.

Furthermore, some unsuccessful plaintiffs had attractive lifestyles. For example, one plaintiff, a psychiatrist who taught at Yale University, alleged that he was falsely arrested outside a local department store while he was gathering signatures for a petition urging the impeachment of former President Nixon. Court File, Abramovitz v. DiLieto, No. N-74248 (D. Conn., filed Oct. 21, 1974). One attorney suggested that the jurors were prejudiced against this plaintiff because he was a professor at Yale. P. Naples.

78. Court File, Garcia v. Carozza, No. N-74-51 (D. Conn., filed Feb. 27, 1974).

79. Court File, Williams v. Dilieto, No. 15646 (D. Conn., filed Feb. 28, 1973).

80. P. Calhoun.

81. Court File, Acampora v. D'Urso, No. N-75-134 (D. Conn., filed May 23, 1975).

82. In a suit brought by the administrator of the deceased's estate, it was shown that the deceased was a furniture mover with a net worth of $\$ 133.82$; he had filed no income tax returns for the past three years. Court File, Gonzales v. Ganley, No. 14383 (D. Conn., filed May 4, 1971). 
The jurors were emphatic in describing what it was about the plaintiffs that bothered them. ${ }^{83}$ A juror said, "The plaintiff's life style was what caused his problems." ${ }^{* 1}$ One juror replied nothing more than "[i]mmoral" to the question of how the plaintiff's lifestyle affected his verdict. ${ }^{85}$ Another respondent wrote that "[i]t was their obvious contempt for law and order" and their "out 'looking for a fight attitude" "\$8 that affected his verdict.

Even some of the jurors who denied that the plaintiff's lifestyle had any effect upon them nevertheless offered revealing information. One juror disclaimed any effect on her personally, but was "positive" that the plaintiff's lifestyle affected other jurors. ${ }^{87}$ Another, who claimed that the plaintiff's lifestyle did not influence him, went on to say that "[w] here he was living, his girl friend, the witnesses he produced-I am putting collectively into 'lifestyle.' They all contributed to lack of credibility." 88

Two jurors said that the plaintiffs' lifestyles affected them in favor of the plaintiffs. One explained that the plaintiff, who was victorious at trial, was helped by the fact that he was a solid citizen: "He is the head of his household and resides there with his wife and family." 89 The other juror was obviously aware of potential bias:

83. A series of items on the questionnaire concerned lifestyle prejudice: jurors were asked, (1) "Did the plaintiff's lifestyle affect your verdict?" (2) "If yes, in what way was your verdict affected?" and (3) "If yes, please write in the space below what it was about the plaintiff's lifestyle that affected your verdict." See Appendix 2, question 6 . No juror answered that he had been influenced "greatly" by the plaintiff's lifestyle, but 10 said that the lifestyle had "some" effect. Fifty-nine jurors said the lifestyle had no effect.

When asked how the plaintiff's lifestyle affected them, six jurors said "against the plaintiff." These answers came from jurors on five different trials, four of which resulted in a defendant's verdict, and one of which had a jury deadlock. The plaintiff in one case was connected with illicit drug traffic and had a long police record that included several serious convictions. Court File, Clemons v. DiLieto, No. 14660 (D. Conn., filed Oct. 6, 1971). Another plaintiff, carrying a bullwhip, was stopped by the police while he was walking down a city street. Court File, Rawls v. Dilieto, No. 14751 (D. Conn., filed Nov. 26, 1971).

Even though the questionnaire item used the nonpejorative term "lifestyle" in asking about possible prejudice, it is suspected that some jurors were reluctant to admit their biases. Restrictions placed on the questionnaire prevented asking jurors whether other jurors exhibited such prejudice. See note 30 supra.

84. Juror \#10, in Clemons v. DiLieto, No. 14660 (D. Conn., filed Oct. 6, 1971) (hung jury).

85. Juror \#30, in Rawls v. DiLieto, No. 14751 (D. Conn., filed Nov. 26, 1971) (defendant's verdict).

86. Juror \#159, in Acampora v. D'Urso, No. N-75-134 (D. Conn., filed May 23, 1975) (defendant's verdict).

87. Juror \#114, in Penque v. Runlett, No. N-74-237 (D. Conn., filed Oct. 11, 1974) (hung jury).

88. Juror \#39, in Bell v. White, No. 14836 (D. Conn., filed Jan. 10, 1972) (defendant's verdict).

89. Juror \#61, in DelVecchio v. Dana, No. 15198 (D. Conn., filed July 20, 1972) (plaintiff's verdict) (white garage mechanic, married, two children). 
In an attempt to counter my own and others prejudices, weighted the evidence of the plaintiff a bit more carefully \& heavily. At best it was difficult to remain unbiased one way or the other as plaintiff was black with a police record and friends of the same description. ${ }^{30}$

A frequent and salient indicator of the plaintiff's lifestyle-past criminal record-may have particularly affected jurors. At least eight of the unsuccessful plaintiffs had prior criminal records that often included multiple convictions.91 Excluding the Cocaine-Quinine case, one of the four successful plaintiffs had one criminal conviction; the other three had none. ${ }^{92}$ Criminal records seem also to have affected the Cocaine-Quinine trial. The jurors in that trial were aware of the felony convictions of two of the successful plaintiffs, but the arrest record of a third was not in evidence. ${ }^{93}$ Although the injuries of the first two plaintiffs were more serious than those of the third, ${ }^{94}$ the former received $\$ 2000^{95}$ and $\$ 500,{ }^{96}$ respectively, and the latter received $\$ 13,000.97$

The jurors' comments reveal a strong negative reaction toward plaintiffs who had experienced previous trouble with the law. One juror questioned the credibility of the plaintiff, explaining: "The plaintiff \& his witnesses were obviously black and streetwise, prostitutes,

90. Juror \#15, in Clemons v. Dilieto, No. 14660 (D. Conn., filed Oct. 6, 1971) (defendant's verdict) (black with 30 prior arrests, many convictions).

91. The criminal records ranged from one conviction for the sale of narcotics, Court File, Gonzales v. Ganley, No. 14383 (D. Conn., filed May 4, 1971), to numerous convictions on 30 prior arrests including 2 drug offenses, 11 assaults, and 1 rape. Court File, Clemons v. Dilieto, No. 14660 (D. Conn., filed Oct. 6, 1971). Prior criminal records were present in at least six other cases. Court File, Acampora v. D'Urso, No. N-75-134 (D. Conn., filed May 23, 1975) (information about criminal record from juror comments); Court File, Gaddy ex rel. Jackson v. Gaglione, No. N-75-97 (D. Conn., filed Apr. 7, 1975) (information about criminal record from juror comments); Court File, Penque v. Runlett, No. N-74-237 (D. Conn., filed Oct. 11, 1974) (information about criminal record from juror comments); Court File, Guest v. Horner, No. 15257 (D. Conn., filed Aug. 15, 1972); Court File, Rawls v. DiLieto, No. 14751 (D. Conn., filed Nov. 26, 1971); Court File, Jones v. City of Hartford, No. 13991 (D. Conn., filed Aug. 24, 1970). Other unsuccessful plaintiffs may have had criminal records that were not indicated by the data.

92. One plaintiff was on probation for a robbery conviction at the time of the alleged misconduct. Court File, Delecke ex rel. Delecke v. Tsolis, No. 15244 (D. Conn., filed Aug. 10, 1972). The other three successful plaintiffs had no previous arrests. Court File, Williams v. DiLieto, No. 15646 (D. Conn., filed Feb. 28, 1973); Court File, DelVecchio v: Dana, No. 15198 (D. Conn., filed July 20, 1972); Court File, Martin v. Consiglio, No. 14741 (D. Conn., filed Nov. 19, 1971).

93. D. Moore.

94. Interview with attorney of a party (name withheld).

95. Court File, Gray v. DiLieto, No. 14640 (D. Conn., filed Sept. 21, 1971).

96. Court File, Smith v. Dilicto, No. 14624 (D. Conn., filed Sept. 15, 1971).

97. Court File, Ramos v. Dilieto, No. 14652 (D. Conn., filed Sept. 30, 1971). 
junkies-one currently serving a sentence. Against two white policemen. In this case, I felt it came down to whom did I believe more. A difficult choice to fairly make based upon courtroom proceedings only." 98 Although the Federal Rules of Evidence allow introduction of a witness's prior convictions only in order to impeach his credibility, ${ }^{99}$ this juror indicated that the decisive factor for him in a difficult case was that the plaintiff and his witnesses were black and streetwise, and had criminal records.

Another juror blandly stated that the plaintiff "had been previously arrested," and "the police action was justified."100 A third juror, like the first, suggested a connection between criminal activity and minority group membership:

I've seen quite a few changes in the law since my youth. We are now at the age of protecting minority groups, criminals, etc. under the guise of people's rights. Twisting of laws by "smart" attornies, securing large damage claims, etc. has made a farce out of some court cases. Vandalism, violence, muggings, etc. has made a tremendous upsurge. We need to get back to the basic law-"Eye for an Eye." 101

One attorney emphasized the importance of the "middle-classness" of the plaintiff; 102 many others mentioned that the plaintiff's lifestyle $\mathrm{e}^{\mathbf{1 0 3}}$ or criminal record ${ }^{104}$ was likely to influence the jury's decision.

In sum, it is clear that jurors were not impartial, but were frequently biased against the plaintiffs in section 1983 suits brought against police. The outcomes of the suits, the damages awarded, the comments of jurors, and the remarks of attorneys indicated bias against nonwhite plaintiffs. Similar data demonstrate that jurors were prejudiced against plaintiffs with nonmiddle-class lifestyles, and particularly against plaintiffs with prior criminal records.

98. Juror \#15, in Clemons v. DiLieto, No. 14660 (D. Conn., filed Oct. 6, 1971) (defendant's verdict).

99. FED. R. Evid. 609(a).

100. Juror \#115, in Penque v. Runlett, No. N-74-237 (D. Conn., filed Oct. 11, 1974) (hung jury).

101. Juror \#159, in Acampora v. D'Urso, No. N-75-134 (D. Conn., filed May 23, 1975) (defendant's verdict).

102. P. Calhoun.

103. Seven attorneys said that the plaintiff's lifestyle was one of the most important factors in determining the outcome of these suits. P. Calhoun, P. Silliman, D. Chao, D. Delmonico, D. Dwight, D. Griswold, D. Moore.

104. The plaintiff's criminal record was mentioned by seven attorneys as one of the most important factors in determining the outcome of the cases. P. Calhoun, P. Rudy, P. deVille, D. Arcadia, D. Leon, D. Moore, D. Oxford. 


\section{B. Bias in Favor of Police Officers}

The Project measured the jury appeal of defendant policemen, because it was thought that police might profit from the aura of authority and honesty surrounding their office. ${ }^{105}$ Jurors were questioned about their reactions to police as defendants, and the opinions of judges and attorneys were also sought. The influence on jury decisions of the good faith defense, available to police officers in section 1983 suits, also was examined.

\section{Description of Pro-Police Bias}

An analysis of juror comments, along with the observations of experienced attorneys and judges, presents substantial evidence of a propolice bias. ${ }^{106}$ According to one juror:

I feel we have handcuffed our policemen because they are afraid of misconduct suits. How can a policeman do his job in handling a rowdy or rough person and still protect himself without using some excessive force? I'd like to see how! We need to back up our policeman, encourage them if they do a good job-be proud of them, instead of continually harassing them. ${ }^{107}$

A second juror admitted he gave the defendant the benefit of any doubt because he was a policeman acting in the course of his duties:

There seemed to be right \& wrong on both sides. The reason I leaned toward defendant rather than plaintiff was because defendant was acting under request by citizens \& instruction by (Police) Dept.

....

Had defendant not been an officer sent in response to a request, my decision might have been otherwise. ${ }^{108}$

Another juror, who said he was not affected by the defendant's status, thought that some jurors were "reluctant" to find a police officer liable, even when the weight of the evidence favored the plaintiff. ${ }^{109}$

105. See, e.g., Newman, supra note 3, at 454; Note, supra note 5, at 923.

106. Examining the outcome of the trials was not helpful. Because all of the defendants were police officers, no comparison of verdicts could be made.

107. Juror \#159, in Acampora v. D'Urso, No. N-75-134 (D. Conn., filed May 23, 1975) (defendant's verdict).

108. Juror \#93, in Brown v. Osborn, No. 15776 (D. Conn., filed June 13, 1973) (defendant's verdict) (emphasis in original).

109. Juror \#116, in Penque v. Runlett, No. N-74-237 (D. Conn., filed Oct. 11, 1974) (hung jury) ("It seems to me that where a police or law enforcement agent is a defendent in a case concerning John $Q$. Citizen; some juror are reluctant to find the police officer guilty. Even when the evidents points to a guilty verdict.") 
Similarly, another jury member seemed distressed by the pro-police bias he noted among his fellows: "People are in love with their law enforcement agencies, but they are just as crooked as the crooks." 110

One juror disclosed a presumption in favor of defendants in police misconduct suits even as he recognized the officers' imperfections:

Traditionally this case is "good guys" vs "bad guys"-only now the "bad" are using the law against the "good." Realizing policemen are human beings with all accompanying imperfections, one cannot automatically judge them right. The decision as to where the line between reasonable and excessive force is calls for much thought \& consideration. ${ }^{111}$

Another juror, who voted to hold a police defendant liable in an illegal search case, expressed a similar presumption, but in this instance it was overcome by the facts of the case: "It was difficult to realize an officer could do wrong, knowing the law. Easy [to decide the case] because it was obviously wrong in the manner it was done." 112

Juror comments regarding police defendants reveal varying degrees of prejudice. Some can be categorized as examples of blatant pro-police bias, others as weaker statements of a presumption in favor of police officers. Nonetheless, the importance of the bias should not be underestimated. Plaintiffs and defendants in these cases usually offer radically different versions of the facts, ${ }^{113}$ and testimony that corroborates the story of either side is often unavailable because "few arrests, searches, or uses of force occur in the presence of disinterested witnesses." 114 In such cases, if the defendant begins the trial with an edge in credibility, the likelihood that the advantage will be overcome is small; if the defendant benefits also from actual prejudice among the jurors, the outcome is almost certain. In order to prevail, the plaintiff must prove the defendant's liability by much more than the legally mandated preponderance of the evidence.

The attorney interviews also suggest that police officers have an advantage. This advantage was more often described as a pro-police bias

110. Juror \#155, in Gaddy ex rel. Jackson v. Gaglione, No. N-75-97 (D. Conn., filed Apr. 7, 1975) (defendant's verdict). This juror claimed to be the only proplaintiff member of the jury; however, he made the vote unanimous after an hour of deliberation.

111. Juror \#20, in Clemons v. Dilieto, No. 14660 (D. Conn., filed Oct. 6, 1971) (defendant's verdict) (emphasis in original).

112. Juror \#63, in DelVecchio v. Dana, No. 15198 (D. Conn., filed July 20, 1972) (plaintiff's verdict). In this case the judge charged that the search warrant was invalid and violated the requirements of the Fourth Amendment.

113. D. Naples, M. Malone, J. York. One juror stated that the trial "resolved itself into the relative credibility of each side." Juror \#39, in Bell v. White, No. 14836 (D. Conn., filed Jan. 10, 1972) (defendant's verdict).

114. Newman, supra note 3 , at 464 . 
than as a prejudice of jurors against plaintiffs. ${ }^{115}$ One attorney, who had handled police misconduct cases as both a plaintiff's and a defendant's advocate, thought that the "[p]olice come in with a big advantage." 116 Another explained metaphorically that "[n]o one likes to think the Good Humor Man is a rapist." 117 Several attorneys spoke of a pro-police bias of "the man in the street" who has a natural sympathy toward police officers. ${ }^{118}$ An attorney who represented defendants said he had an advantage because he "had the cops." He added, "[c]ops are not inherently more credible; people want to support the police."119 Another attorney said that "juries know misconduct goes on and feel like it should go on more often." 120 Moreover, the attorneys' perceptions of juror bias in favor of police affected their handling of these cases. One plaintiffs' attorney settled his police misconduct suits out of court, for less than he settled his other cases, because he felt the police had the edge in court. ${ }^{121} \mathrm{~A}$ defense attorney stated that he had little inclination to settle police misconduct cases "if the defendants' position is at all respectable, because the jury is law enforcement oriented." 122

\section{The Good Faith Defense}

One of the most discussed legal concepts in section 1983 police misconduct litigation is the good faith defense. ${ }^{123}$ By proving that he

115. Thitty-three of the 40 attorneys interviewed expressed an opinion on juror bias. Twenty-four said that jurors were biased in favor of the police; 22 characterized the bias as being against the plaintiffs. Defendants' attorneys as well as plaintiffs' attorneys pointed to jury bias: statements by defendants' attorneys that juries are biased in favor of their client are not self-serving, for they neither add prestige to their victories nor explain their defeats. Six attorneys (three plaintiffs' attorneys, two defendants' attorneys, and one mixed attorney) responded that there is only pro-police bias. P. Belmont, P. Branford, P. Calhoun, D. George, D. Kavanaugh, M. Edwards. Four attorneys (one plaintiff' attorney and three defendants' attorneys) responded that there is only bias against the plaintiff. $P$. Saybrook, D. Arcadia, D. Dwight, D. Moore. Eighteen other attorneys (eight plaintiffs' attorneys, seven defendants' attorneys, and three mixed attorneys) noted both pro-police and antiplaintiff biases. P. Broadway, P. Davenport, P. Gypsy, P. Rudy, P. Sherman, P. Silliman, P. Stiles, P. Trumbull, D. Delmonico, D. England, D. Leon, D. Naples, D. Oxford, D. Pierson, D. Wilfred, H. Blake, M. Foundry, M. Malone.

Four attorneys stated that juries were not biased in favor of or against either side. $D$. Chao, D. Clark, D. Lad, D. Zapata. Another attorney pointed to bias against the defendant. D. Berkeley.

This classification does not distinguish between attorneys who declared their conclusions of jury bias and attorneys whose responses strongly imply such conclusions.

116. M. Blake.

117. D. England.

118. P. Davenport; accord, D. Griswold, M. Malone.

119. D. Naples.

120. M. Malone.

121. P. Calhoun.

122. D. Kavanaugh.

123. E.g., Nahmod, supra note 22, at 26; Comment, supra note 12, at 951-53. 
believed in good faith that his actions were lawful, and that such belief was reasonable, a police defendant can avoid liability for actions that would otherwise violate a citizen's constitutional rights. ${ }^{124}$ The defense has been criticized because its logic is self-contained and circular. ${ }^{125}$ Additionally, it has been argued that the jury misapplies the defense by focusing on the subjective good faith of the police officer and ignoring the objective standard of reasonableness. ${ }^{126}$ The defense thus becomes the means through which jurors, already inclined to favor police defendants, express their bias. ${ }^{127}$

The Project attempted to determine whether the jurors correctly understood and applied the good faith defense. ${ }^{128}$ Attorneys were also questioned about the defense and its effect on jurors. ${ }^{129}$ On the basis of this examination, it was determined that the good faith defense was far less important to the outcome of the jury trials than was anticipated. Moreover, the jurors' comprehension of the defense could not be determined from the data.

The good faith defense was of limited significance for three reasons: the jurors did not remember it; many attorneys either did not understand it or were not aware of it; and the defense was not charged in

124. Bivens v. Six Unknown Named Agents, 456 F.2d 1339, 1348 (2d Cir. 1972).

125. Newman, supra note 3 , at 460 . For example, the plaintiff's cause of action for a false arrest requires him to show that the arrest was not reasonably based on probable cause. If the officer reasonably believed that he had probable cause to make the unlawful arrest, then he is exonerated because of the good faith defense. But, as Judge Newman points out, "[s]urely the officer could not reasonably believe that there was probable cause for an unlawful arrest, for an unlawful arrest is by definition an arrest for which a prudent police officer could not reasonably believe there was probable cause." Id. (emphasis in original).

126. Theis, supra note 12, at 1009-12; P. Davenport ("If police [officer convinces] the jury that he believed he acted right to do what he did, even if [it is] absurd, then he wins.")

127. P. Sherman (defense allows jurors "to vote their hearts, not their heads"); M. Blake ("They are leaning toward the police already. If they hear 'good faith' that may be all they need to vote their leaning."); M. Foundry ("[The defense provides the] jury a comfortable way to say 'yes, the defendant did something wrong, but he does not to have to pay.' . . . 'Subjective' may be three-fourths of the test in the jurors' minds.")

128. A series of questions was designed to test the jurors' knowledge of the doctrine, and to discover how it influenced their deliberations:

Appendix 2, question 13: There is a doctrine, sometimes called the good faith defense, which says that if a police officer believed, in good faith, that his conduct was lawful and if his belief was reasonable, then he is not liable for his actions. (a) Was this doctrine mentioned by the judge? (b) Did you feel that this doctrine was adequately explained by the judge? (c) Did this doctrine affect your verdict? (d) How did this doctrine affect your verdict? (e) Please write in the space below the reason why the doctrine affected your verdict this way.

Appendix 2, question 9: Did the police officer think his actions were reasonable? Regardless of what the police officer thought, did you think his actions were reasonable?

129. See Appendix 1, questions 15-18. 
some of the cases in the sample. Despite an explanation of the good faith defense in the questionnaire, only six jurors remembered that the defense had been mentioned by the judge. ${ }^{130}$ This lack of recollection contrasts sharply with the jurors' ability to remember such details as the amount of damages they awarded and the plaintiff's lifestyle. ${ }^{131}$ This comparison suggests that the good faith defense had little impact on the jurors' verdicts.

The attorneys also displayed a surprising lack of knowledge about the defense. ${ }^{132}$ Even attorneys who said the defense was important ${ }^{133}$ frequently needed prompting on its operation. Answers tended to be vague and, in contrast to other answers, rarely referred to specific cases for illustration..$^{134}$ Finally, the importance of the defense was severely diminished because the judge did not charge it in at least eight of the jury cases in the Project sample. ${ }^{135}$

130. Only two of the six answers were capable of verification. See p. 805 infra. One juror remembered that the good faith defense was charged by the judge; however, a second juror who sat on the same trial remembered that the defense was not charged. That trial resulted in a hung jury; on retrial the good faith defense was not mentioned. Court File, Clemons v. DiLieto, No. 14660 (D. Conn., filed Oct. 6, 1971). This raises additional doubts about the accuracy of jurors' memories regarding the good faith defense.

131. E.g., Juror \#85, in Williams v. Dilieto, No. 15646 (D. Conn., filed Feb. 28, 1973) (remembered that award was for $\$ 1366$ ); Juror \#39, in Bell v. White, No. 14836 (D. Conn., filed Jan. 10, 1972) (described plaintiff's lifestyle in terms of residence and friends).

132. Thirty percent of the attorneys either did not know what the defense was or had not used it. Thus, when questioned about the importance of the defense, see Appendix 1 , question 15, three attorneys admitted they were unfamiliar with it. D. Griswold, D. Kavanaugh, M. Edwards. Another four attorneys stated that the defense was never an issue in their cases, although it is not clear whether this was because the defense was legally not applicable, see note 135 infra, or because they were ignorant of the doctrine. P. deVille, D. Consiglio, D. Oxford, M. Malone. Three attorneys did not answer the question. P. Belmont, P. Trumbull, D. Millpond. One defense attorney who had represented police officers in numerous cases "never pleaded" the good faith defense. D. Berkeley. Finally, one attorney displayed an obvious lack of comprehension: "Yes, it's important; the good faith of [the plaintiff] is an issue." $P$. Garden.

133. Twenty-two attorneys believed the good faith defense was important. P. Branford, P. Broadway, P. Calhoun, P. Davenport, P. Rudy, P. Sherman, P. Silliman, D. Arcadia, D. Chao, D. Clark, D. Delmonico, D. Dwight, D. England, D. Kaysey, D. Lad, D. Leon, D. Moore, D. Pierson, D. Wilfred, D. Zapata, M. Blake, M. Foundry. The number of "important" responses may have been inflated somewhat by prompting. Six attorneys did not think the defense was important. P. Fitzwilly, P. Gypsy, P. Saybrook, P. Stiles, D. George, D. Naples.

134. E.g., D. Lad ("Any defense you have is important.")

135. The data indicate that the good faith defense was charged by the judge in six cases and not charged in eight cases. In 10 cases it cannot be determined whether the defense was charged.

From interrogatories to the jury it was clear that the good faith defense was not charged in three trials. Court File, James v. DiLieto, No. N-74-247 (D. Conn., filed Oct. 21, 1974); Court File, Davis v. Gianotti, No. 15157 (D. Conn., filed July 6, 1972); Court File, Clemons v. Dilieto, No. 14660 (D. Conn., filed Oct. 6, 1971). One judge, as a matter of policy, does not charge the good faith defense in excessive force cases. This judge presided over five excessive force trials in the sample. Court File, Acampora v. D'Urso, No. 
The data on jurors' comprehension of the good faith defense are inconclusive. On the one hand, the majority of jurors did not remember if the judge had mentioned the defense. ${ }^{136}$ On the other hand, in one case two jurors remembered that the defense had been charged and they seem to have applied it correctly. ${ }^{137}$ Also, questions that probed the juror's attitude about the objective and subjective reasonableness of the defendant's actions were answered by the majority of jurors in a manner consistent with their verdicts. ${ }^{138}$ The jurors thus showed themselves capable of making the distinction between subjective and objective reasonableness. Nevertheless, because of their inability to remember if such a distinction was made during their deliberations, it is impossible to determine if the jurors understood the good faith defense at the time of trial.

N-75-134 (D. Conn., filed May 23, 1975); Court File, Gaddy ex rel. Jackson v. Gaglione, No. N-75-97 (D. Conn., filed Apr. 7, 1975); Court File, Worrell v. Downs, No. N-75-83 (D. Conn., filed Mar. 27, 1975); Court File, Trent v. Summa, No. N-75-55 (D. Conn., filed Mar. 3, 1975); Court File, Guest v. Horner, No. 15257 (D. Conn., filed Aug. 15, 1972).

Although it is not known whether the defense was charged in 10 trials, the data demonstrate that the jury was instructed on the good faith defense in six others. Court File, Burns v. Celentano, No. 15469 (D. Conn., filed Nov. 28, 1972); Court File, Delecke ex rel. Delecke v. Tsolis, No. 15244 (D. Conn., filed Aug. 10, 1972); Court File, DelVecchio v. Dana, No. 15198 (D. Conn., filed July 20, 1972); Court File, McEachern v. Consiglio, No. 14908 (D. Conn., filed Feb. 23, 1972); Court File, Martin v. Consiglio, No. 14741 (D. Conn., filed Nov. 19, 1971); Court File, Ramos v. DiLieto, No. 14652 (D. Conn., filed Sept. 30, 1971); Court File, Gray v. DiLieto, No. 14640 (D. Conn., filed Sept. 21, 1971); Court File, Smith v. Dilieto, No. 14624 (D. Conn., filed Sept. 15, 1971).

136. In answer to the question, "Was this doctrine mentioned by the judge?," six jurors answered "yes," Il jurors answered "no," and 52 jurors answered "I do not remember." See Appendix 2, question 13.

137. Juror \#62, in DelVecchio v. Dana, No. 15198 (D. Conn., filed July 20, 1972) ("The police officer in clear conscionse, and he should have received proper training in entering someones' home, could not say that he 'believed in good faith' that what he did was right.") A second juror found the defendant's assertion of good faith unreasonable:

It was explained that officer Dana had several training courses dealing in serving of search warrants. He had served several hundred but he failed to note that the warrant contained only general statements of material to be found. Search warrants must list the exact items to be stolen. He should have known this.

Juror \#64, in DelVecchio v. Dana, No. 15198 (D. Conn., filed July 20, 1972).

In DelVecchio, the plaintiff alleged an unlawful search and the judge charged the jury that the defendant's search warrant was illegal on its face. Court File, DelVecchio v. Dana, No. 15198 (D. Conn., filed July 20, 1972). Evidence at trial showed that the police officer had altered the search warrant after the search in order to make it appear legal. Because the judge had charged that the warrant was illegal, the only question the jury was left to decide was whether the police officer was absolved of liability because he had proved the elements of the good faith defense. The defendant was found liable.

138. Only three of 54 answers were inconsistent with the verdict. The juror should have voted to acquit the defendant if he thought that the defendant's actions were objectively reasonable. The juror should have found the defendant liable if the police officer's actions were not objectively reasonable. See Appendix 2, question 9 .

All of the 70 jurors who responded believed that the police officer thought his actions were legal. Two jurors stated that the defendant's actions were unreasonable, yet rendered a verdict for the defense. Only one juror who thought that the police officer's actions were reasonable nevertheless rendered a verdict for the plaintiff. 
Significant bias in favor of the police officers, then, was indicated by the comments of jurors and was confirmed by attorneys. The biases of jurors varied in strength, from outright prejudice to more subtle presumptions, often equally damaging to the plaintiff's case. Whether the "good faith" defense intensified pro-police biases could not be determined from the data; but, in any event, the defense seemed to have little effect on the outcomes of the studied trials.

\section{Bias Inherent in the Jury Selection Process}

The Project data also reveal two serious problems of bias inherent in the jury selection procedure used in the section 1983 cases studied. First, blacks were seriously underrepresented on the juries; second, a large percentage of the jurors sat on more than one police misconduct trial, often within a short period of time.

\section{Scarcity of Black Jurors}

In the Project's sample of jury trials, blacks occupied only two of the 163 juror positions. ${ }^{139}$ Jurors are chosen from the list of registered voters in the territorial area of the court division. ${ }^{140}$ Blacks do not register to vote in the same proportions as do whites, and thus fewer are included on the juror lists. ${ }^{141}$ In addition, the area of the New Haven Division includes many suburban towns that have relatively small black populations. ${ }^{142}$ Some defense attorneys frankly stated that they prefer all-white

139. The court records do not include a separate category "Hispanic" under ethnic classification. Hispanics, therefore, are included in the classification "white."

140. In the District of Connecticut, the first step in selecting jurors is to pick a Master Jury Wheel by choosing at random one percent of the registered voters in each political subdivision lying within the Division. When jurors are needed, names are drawn by lot from the Master Jury Wheel. These people are sent a juror qualification form. Those who complete the form and are not excused for cause make up the Qualified Jury Wheel from which names are drawn randomly to make up jury panels. When presented with a panel, attorneys listen to the voir dire conducted by the judge. Afterwards they may challenge panel members for cause and exercise their peremptory challenges. The remaining panel members compose the petit jury. See D. Conn. Jury Selection Plan (promulgated Sept. 23, 1968; amended June 10, 1975).

141. See United States v. Jenkins, 496 F.2d 57, 64 (2d Cir. 1974):

The percentage of Negroes among the adult population (i.e. aged 21 years or older)

in the New Haven division is $5.45 \%$, according to the United States Census. On the other hand, questionnaires sent out to members of the New Haven division jury pools from 1969 to 1973 revealed that only $3.3 \%$ were Negroes.

Cf. AMERICAN JURY SYSTEM, supra note 7, at 22 (voter registration lists do not represent cross-section of population).

142. P. Broadway, P. Davenport, P. Sherman, M. Foundry, M. Malone.

In the most recent update of the Qualified Jury Wheel in the New Haven Division, 1000 people were sent juror qualification forms. Of the 1000 persons, 809 responded; 15 of these, or less than two percent, were "nonwhite." Interview with Frances Consiglio, 
juries; ${ }^{143}$ when only one or two blacks appear on a basic panel of thirty from which a jury of six is to be chosen, such an attorney can easily eliminate the black jurors through peremptory challenges. ${ }^{1+4}$

The two black jurors in the Project sample sat on different trials; these were the only two trials that resulted in hung juries. ${ }^{145}$ Although such an occurrence can be explained as a coincidence, the inference might be drawn that the presence of black jurors makes consensus more difficult because it inhibits the operation of racial prejudice or other antiplaintiff or pro-police biases. One juror, who sat on a hung jury, supported this inference with his comment that " 8 people with different back rounds, lifestyles and seeing and hearing the evidence differently could not agree on the facts or lack of facts to convict the defendants." 146

The same explanation was offered by a juror from the other hung jury: "Considering the evidence presented by both sides $I$ had no trouble in making up my mind. For what its worth-I felt we were hung because of our lifestyles and our own dealings with the policegood-bad or indifferent." 147 Because the participants in the delibera-

Assistant Clerk of Court, New Haven Division (May 2, 1978) [hereinafter cited as Consiglio Interview].

These figures contrast markedly with statistics compiled by the Census Bureau. The population of Connecticut in 1970 was $6.5 \%$ "Negro and other races," as opposed to "white." The counties of Middlesex, New Haven, and New London, which comprise the New Haven Division, contain $114,816,744,948$, and 230,348 persons, respectively. The percentages of "Negro and other races" in their populations are $3.2 \%, 8.1 \%$, and $4.0 \%$, respectively. Thus, a weighted average of the "Negro and other races" population in the counties is 6.7\%. I Bureau of Census, Social and Economic Statistics Administration, U.S. Department of Commerce, 1970 Census of Population pt. 8, ch. B, at 35-37 \& Table 16. "Negroes" preponderate the category "Negro and other races": in 1970 there were in Connecticut 3,031,709 persons, of whom 2,835,458 were white, 181,177 were Negro, 2,222 were Indian, 1,621 Were Japanese, 2,209 were Chinese, 2,177 were Filipino, and 6,845 fit none of the above categories. Id. at 38 Table 17.

143. One defense attorney explained that "You pick all white juries; pick business types concerned about security; working class types concerned about street crime." D. Naples; accord, D. Dwight (desired older, male, white jurors); D. Zapata ("right kind of jury" was one with middle-class, suburban, white members).

144. See American Jury SYstem, supra note 7, at 24-25; cf. United States v. Newman, 549 F.2d 240 (2d Cir. 1977) (mandamus granted to vacate district court's disallowance of peremptory challenges used by Gorernment to eliminate all four black venireman because Government exhibited pattern of excessive challenges against blacks).

145. Court File, Penque v. Runlett, No. N-74-237 (D. Conn., filed Oct. 11, 1974) (white plaintiff); Court File, Clemons v. DiLieto, No. 14660 (D. Conn., filed Oct. 6, 1971) (black plaintiff; defendant's verdict).

146. Juror \#10, in Clemons v. Dilicto, No. 14660 (D. Conn., filed Oct. 6, 1971).

117. Juror \#115, in Penque v. Runlett, No. N-74-237 (D. Conn. filed Oct. 11, 1974). A juror in another case suggested that black jurors would have added a different perspective: I seriously question the ability of anyone juror no matter how concientious, to remain impartial and logical in a case where it is possible to follow prejudice or try to counteract it. Either way the scales are not balanced. . . . Better legal guidelines would have softened the uneasiness felt about this case as would several black jurors.

Juror \#15, in Clemons v. Dilieto, No. 14660 (D. Conn., filed Oct. 6, 1971) (black plaintiff; defendant's verdict). 
tions explain their inability to reach a verdict as a function of different lifestyles, backgrounds, and dealings with the police, and because defense attorneys concede that they prefer all-white, middle-class juries, it is clear that a jury selection process that regularly includes few blacks systematically discriminates in favor of defendants in police misconduct suits.

\section{Repeat Jurors}

It was not unusual for a juror to sit on more than one police misconduct case because many petit juries are chosen from the same pool of veniremen. ${ }^{148}$ Of the 163 juror positions in the studied cases, thirtynine (approximately twenty-five percent) were filled by jurors who had already deliberated on at least one police misconduct trial. One juror sat on four police misconduct trials, six sat on three, and twenty-four sat on two.

The plaintiffs did not fare well in the trials in which repeat jurors deliberated. In the ten trials in which the jury included more than one person who had previously been a juror in a police misconduct case, no plaintiff was successful.149 At times, jurors sat on police misconduct cases in which the parties were represented by the same attorneys they had witnessed before. ${ }^{150}$ Three attorneys volunteered, without being

148. For example, several police misconduct cases may be docketed for trial during a certain month. The juries for these and other trials may be chosen on one day at the beginning of the month. Typically, about 100 veniremen are summoned to appear on that day; from the veniremen, panels, usually consisting of 30 persons, are chosen at random. From a panel, attorneys choose the petit jury. After a panel member has been chosen as a juror, he reenters the the pool of veniremen, from which he may again be chosen to serve on a panel and, possibly, to become a juror in another trial. See Consiglio Interview, supra note 142 .

149. The following table, which excludes the two deadlocked juries, shows the relationship between the number of repeat jurors and the outcome of the trial.

Table A: Repeat Jurors

$\begin{array}{cccc}\begin{array}{c}\text { Number of repeat jurors } \\ \text { on jury }\end{array} & \begin{array}{c}\text { Outcome of trial } \\ \text { Plaintiffs' } \\ \text { verdict }\end{array} & \begin{array}{c}\text { Defendants' } \\ \text { verdict }\end{array} \\ 5 & - & 2 \\ 4 & - & 2 \\ 3 & - & 5 \\ 2 & - & 1 \\ & 1 & 2 & 1 \\ \text { Total } & 0 & 3 & 6 \\ & & 5 & 17\end{array}$

150. For example, four members of the jury in Abramovitz v. DiLieto, No. N-74-248 (D. Conn., filed Oct. 21, 1974), were also members of the jury in Gaddy ex rel. Jackson v. Gaglione, No. N-75-97 (D. Conn., filed Apr. 7, 1975). Two of these four jurors together with two other jurors from the Abramovitz trial, served on a third jury, in Acampora v. D'Urso, No. N-75-134 (D. Conn., filed May 23, 1975). These three cases, all with defendants' 
asked, that the existence of repeat jurors in police misconduct cases is highly prejudicial to the plaintiff. ${ }^{151}$ It is not apparent why repeat jurors affect the outcome of a trial; but it is clear that their presence, for whatever reasons, benefits the defendants. .152

\section{Effect on Defendants of Police Misconduct Suits}

The purpose of section 1983 suits against the police is both to compensate individuals for violations of their constitutional rights and to deter police misconduct. ${ }^{153}$ If the deterrent effect depends chiefly upon holding those who are responsible for the misconduct financially accountable, ${ }^{154}$ then it is essential to know who bears the costs of these

verdicts, involved plaintiffs represented by the same attorney, as well as defendants from the same municipality, represented by the Office of the Corporation Counsel.

Repeated appearances of plaintiffs' attorneys may have induced jurors to conclude that the plaintiffs' attorneys were soliciting clients or were bringing actions of doubtful merit. If so, such a conclusion could have caused jurors to disfavor the plaintiffs' claims. The comments of two jurors may illustrate such a prejudice:

This case should never have gone to trial in my opinion. It represents a waste of time and money, because there seemed to be no evidence of misconduct on the part of the policeman. ... I noticed that the plaintiff's lawyer, $\mathrm{Mr}$ in a series of cases of alleged police misconduct.

Juror \#127, in Abramovitz v. Dilieto, No. N-74-248 (D. Conn., filed Oct. 21, 1974) (attorney name withheld);

I felt that the plaintiff's case was blown out of proportion (both by the attorney and the plaintiff's). Too many cases are brought to trial and waste of people's time and money-because somebody's feelings were hurt. People feel they are entitled to a lot of money (attornies \& judges do not help in this cause).

Juror \#159, in Acampora v. D'Urso, No. N-75-134 (D. Conn., filed May 23, 1975). The first juror expressed dislike for the plaintiff's attorney; the second juror answered that he was "neutral."

151. One attorney said that the juries were "lousy" because one plaintiffs' attorney "brings too many cases," and when the jurors see those cases they "start to compare." He added that such comparison made his job "harder." P. Branford. "In federal court the same jurors sit on some of the $\S 1983$ cases. This is terrible. Jurors then can't handle each case individually." M. Blake; see D. Arcadia (jury selection procedure favors defendant).

152. It is possible that jurors hearing their first police misconduct trial may be able to control their prejudices somewhat; but by the time of the second, third, or fourth such trial, the jurors may have greater difficulty. For jurors who share a pro-police bias, it probably is easier to admit that an isolated incident of misconduct could occur than to acknowledge a series of such events. Also, to the extent that a juror feels threatened by the persons who are plaintiffs in these suits, the juror may become more sympathetic to the view that one cannot expect niceties from law enforcement officers who are constantly exposed to threatening individuals.

153. Nahmod, supra note 22, at 10-11; Developments in the Law-Section 1983 and Federalism, 90 HARv. L. Rev. 1133, 1226-27 (1977).

154. The deterrent effect of police misconduct suits may not depend exclusively on the individual suffering a financial loss; a lawsuit also may lead to emotional stress, adverse publicity, and detrimental effects on the officer's career. D. Oxford, P. Belmont. Some officers, because they were deemed violent or troublemakers, were given assignments with little public exposure. D. Oxford, P. Branford.

One police chief explained that the allegations embodied in a complaint alleging brutality or illegal search are news, and often are given front-page treatment by the 
suits. The Project data, however, indicate that both the individual defendants and the police departments are insulated from any financial burden consequent to a section 1983 suit.

\section{A. Effect on Individual Officers}

In the sample cases, municipalities ${ }^{155}$ were not liable under section 1983 for the unconstitutional actions of their employees. ${ }^{156}$ Nonetheless, police officers were provided free legal counsel ${ }^{157}$ and were indemnified for any settlement or judgment by the municipality or its insurance carrier. ${ }^{158}$ Some of the municipalities in the sample were self-insured; ${ }^{159}$ others purchased insurance from a carrier for the bene-

media. O. Mara; see P. Branford, D. Arcadia, D. Naples. The subsequent disposition of the case, be it a defense verdict or an out-of-court settlement at a nominal sum, comes years later without publicity. 0 . Mara.

In Connecticut, the defendant's house, under certain circumstances, can be attached as security for a judgment against him. See FED. R. Crv. P. 64 (in absence of federal law, state law governs attachment); CoNN. GEN. Srat. \$ 52-279 (1977) (attachment of police officer's property allowed if he has been dismissed from police force or if judicial order is obtained). One plaintiff' attorney admitted that an attachment motion can be made for its psychological effect, and not to secure a judgment, which in any event will be paid by the city or insurance company. M. Foundry; see R. SulNick, supra note 17, at 93 (empirical study concluding that civil litigation has effect to extent that superior officers feel stigmatized by successful suits and are aware that departmental funds are significantly reduced).

155. The following is a list of the municipalities that had police officers sued in the sample cases; the number of suits involving each municipality and the Connecticut State Police is given parenthetically: New Haven (71), West Haven (19), Hartford (13), State Police (7), Waterbury (6), Hamden (5), Madison (4), East Haven (3), Naugatuck (3), Branford (2), Bridgeport (2), Milford (2), Ansonia (1), Cheshire (1), Meriden (1), Middlebury (1), Middletown (1), North Branford (1), North Haven (1), Seymour (1), Torrington (l), West Hartford (1), Willimantic (1), and Woodbridge (1).

156. See p. 785 supra.

157. D. Arcadia, D. Berkeley, D. Chao, D. Clark, D. Dwight, D. England, D. George, D. Kaysey, D. Lad, D. Naples, M. Edwards.

158. Five juries awarded monetary damages in seven cases, including three awards in a consolidated trial. One verdict was against an employee of the Madison Police Department, Court File, DelVecchio v. Dana, No. 15198 (D. Conn., filed July 20, 1972), but the judgment was paid by the town of Madison. Interviews with attorneys of the parties (names withheld). Six verdicts were against employees of the New Haven Police Department. Court File, Williams v. DiLieto, No. 15646 (D. Conn., filed Feb. 28, 1973); Court File, Delecke ex rel. Delecke v. Tsolis, No. 15244 (D. Conn., filed Aug. 10, 1972); Court File, Martin v. Consiglio, No. 14741 (D. Conn., filed Nov. 19, 1971); Court File, Ramos v. Dilieto, No. 14652 (D. Conn., filed Sept. 30, 1971); Court File, Gray v. DiLieto, No. 14640 (D. Conn., filed Sept. 21, 1971); Court File, Smith v. Dilieto, No. 14624 (D. Conn., filed Sept. 15, 1971). In each case, the judgments, including one punitive damage award, were paid by the City of New Haven. Interview with attorneys of the parties (names withheld).

Forty-two of the studied cases were concluded by a stipulated dismissal, that is, a settlement out of court. Through interviews with attorneys it was possible to collect settlement figures for 32 of these suits. With one exception, attorneys who supplied these damage figures could point to no case in which the individual officer ultimately bore the cost of the settlement. For an explanation of the exception, see p. 811 infra.

159. Three of the larger municipalities in the study-Bridgeport, New Haven, and Waterbury-were self-insured because premiums were expensive in urban areas. D. Arcadia, D. Berkeley, D. Chao, D. Kaysey. 
fit of their employees. ${ }^{160}$ Once a complaint was filed against an officer, the insurance company was notified, and it retained an attorney to represent the police officer. ${ }^{161}$ If the municipality was self-insured, its corporation counsel handled the police officer's defense. ${ }^{162}$

The individual defendants were almost always indemnified even though both the municipality and the insurance carrier retain the right not to reimburse the police officer if the misconduct was willful, wanton, or outside the scope of the officer's duties. ${ }^{163}$ The importance of this right was stressed by a number of attorneys. ${ }^{164}$ Nevertheless, there were only two instances in which the right was exercised: one case resulted in the officer paying twenty-five dollars, ${ }^{165}$ and the other, involving an off-duty officer, was pending at the conclusion of the field research. ${ }^{160}$ Even in the one case in which a jury awarded punitive damages against a police officer, the municipality indemnified the officer for both the compensatory and punitive portions of the award. ${ }^{107}$

Moreover, no supervisory official in the sample suffered an adverse judgment at trial. ${ }^{168}$ Not only were they never found liable, they were rarely even defendants at trial. Supervisory officials were sued in

160. East Haven, Hartford, Madison, Milford, Naugatuck, and West Haven purchased insurance. D. Clark, D. Consiglio, D. Lad, D. Leon, D. Pierson, M. Edwards.

161. See, e.g., D. Dwight, D. England.

162. See, e.g., D. Chao, D. Naples. In a few cases with multiple defendants, the corporation counsel retained private attorneys to represent individual defendants, thus avoiding a conflict of interest. E.g., Court File, Smith v. DiLieto, No. 14624 (D. Conn., filed Sept. $15,1971)$.

163. The Connecticut indemnity statute, in relevant part, states:

Any town, city or borough, ... shall pay on behalf of any employee of such municipality, ... . all sums which such employee becomes obligated to pay by reason of the liability imposed upon such employee by law for damages awarded for infringement of any person's civil rights or for physical damages to person or property, . . . if the employee, ... . was acting in the performance of his duties and within the scope of his employment, and if such occurrence, accident, physical injury or damage was not the result of any wilful or wanton act of such employee in the discharge of such duty.

Conn. Gen. Stat. $\$ 7-465$ (1977). The statute embodies the policy that a person may not insure against losses caused by his intentional wrongs. See Messersmith v. American Fidelity Co., 232 N.Y. 161, 165, 133 N.E. 432, 433 (1921) (Cardozo, J.) ("[N]o one shall be permitted to take advantage of his own wrong ....")

164. D. Arcadia, D. Berkeley, D. Clark, D. Dwight, D. Kaysey, D. Leon, D. Naples, D. Wilfred, M. Edwards.

165. The total settlement was $\$ 425$; the $\$ 25$ payment was made pursuant to an agreement providing that the settlement would be paid jointly by the officer, the municipality, and the insurance company. The officer, who was in bankruptcy proceedings at the time, paid $\$ 25$ in order to be released from liability. Interview with attorney of a party (case and attorney name withheld).

166. Court File, Gifford v. Rodriguez, No. N-76-157 (D. Conn., filed May 17, 1976).

167. Court File, Delecke ex rel. Delecke v. Tsolis, No. 15244 (D. Conn., filed Aug. 10, 1972).

168. None of the seven plaintiffs' verdicts was against supervisory officials. See note 158 supra (plaintiffs' verdicts). 
eighty-two separate cases; in all but nine, the officials were dismissed as defendants before trial. ${ }^{160}$

Thus, in almost every case, the individual defendant suffered no financial loss because of the suits. If deterrence is predicated upon a police officer being personally accountable in damages to his victim, then there is no example of deterrence in the Project sample.

\section{B. Effect on Police Departments}

There were few changes in police department practices as a result of the section 1983 suits in the Project sample. The only changes in police procedures directly attributable to the suits were the adoption by the Willimantic police department of detailed regulations defining proper police conduct, ${ }^{170}$ the institution by the New Haven Police Department of more accurate and extensive police reports, ${ }^{171}$ and the prohibition of retaliatory arrests of citizens who filed complaints with the New Haven Police Department about an officer's conduct. ${ }^{172}$ No

169. In seven of the nine cases in which supervisory officials were still defendants at trial, they won directed verdicts; in the other two instances the jury found them not liable. This excludes instances in which superiors were kept in the suit in their official capacities only to serve as necessary defendants for purposes of injunctive relief. See note 21 supra.

170. Court File, Hernandez v. Noel, No. 13940 (D. Conn., filed July 13, 1970). The change in regulations resulted from a class action suit brought on behalf of all residents of Willimantic who were of Puerto Rican ancestry and who had been victims of alleged harassment, intimidation, discrimination, and violent conduct by Willimantic police officers. Alleged misconduct included, inter alia, wrongful discharge of firearms, beatings, and false arrests. Instead of money damages, the plaintiffs sought only injunctive relief ordering the discontinuance of these improper actions. $I d$.

The suit was withdrawn with the filing of a six-paragraph stipulation with the court. The stipulation stated that a new police chief had been appointed, that detailed regulations defining proper police conduct had been adopted, that there was to be psychological testing of recruits, and that no admission as to the merits of the complaint was to be implied. $I d$.

171. In the consolidated trial of the Cocaine-Quinine cases, which resulted in three plaintiffs' verdicts, there was testimony that police informants fabricated claims and that police officers filed false case incident reports. Monetary damages were awarded, and a consent decree was authorized, which provided that the reports were to be signed under penalties provided by state law for making a false statement, and that better records of informants were to be kept, including an assessment of their reliability, and of the money paid to them. Court File, Ramos v. DiLieto, No. 14652 (D. Conn., filed Sept. 30, 1971); Court File, Gray v. Dilieto, No. 14640 (D. Conn., filed Sept. 21, 1971); Court File, Smith v. DiLieto, No. 14624 (D. Conn., filed Sept. 15, 1971).

172. Court File, McCue v. Spencer, No. N-75-145 (D. Conn., filed May 30, 1975). The action was brought by plaintiffs who were arrested in an incident at the New Haven Coliseum. The prosecutor entered a nolle prosequi for the charges the next day and the plaintiffs made a complaint to the police department. Subsequently, a new warrant was procured for the plaintiffs' arrest; when one of the plaintiffs returned to the police station to complete a written report upon the request of the defendants, the plaintiff was rearrested. $I d$.

The case was settled on the following terms: "[T]he defendants would pay the plaintiffs 
injunctions ordering changes in police procedures were issued in any case in the sample. ${ }^{173}$

Payments made by municipalities as a result of section 1983 litigation did not generate pressure on the police departments to minimize misconduct. ${ }^{17+}$ Damage awards were infrequent and diminutive; suits were often settled out of court for modest sums. ${ }^{17 \tilde{s}}$ The costs that did exist were hidden; for example, legal work was done by salaried attorneys in the office of the corporation counsel, or by an insurance company as part of the municipality's comprehensive liability insurance coverage. ${ }^{176}$

The lack of significant monetary incentive was combined with a disinclination on the part of some municipalities to discipline their police. Whether because municipal officials were generally sympathetic toward police officers, or because they were dependent politically on the police department, or simply because the plaintiffs in these suits were not members of a politically significant constituency, the attitude of municipal leaders often appeared to be one of complete support for law enforcement agencies. ${ }^{177}$ In one striking illustration of solidarity with the police department, a municipal board of police commissioners decided against disciplining a police officer who had been found liable for his use of excessive force and subsequently promoted him. ${ }^{178}$ In another case, after a police officer had been convicted on criminal charges of brutality and had been given a suspended sentence, the mayor proclaimed that the officer would neither be disciplined nor miss a day's work. ${ }^{179}$

a total of \$2000.00 and the defendant DiLieto would send a letter to the members of the New Haven Police Department instructing them on certain procedures which would as. sure that the misconduct demonstrated in the captioned case would not again occur." Id.

173. Some attorneys said, however, these suits may have contributed to several changes in police practices. Officers in some police departments receive more extensive training now than in the past. D. Clark, D. England, D. Kavanaugh. In addition, legal advisors now review search warrants, D. Clark, D. England; but one attorney asserted that this procedure was instituted in order to increase the conviction rate. P. Calhoun. Finally, two departments have instituted stricter firearms procedures. P. Davenport, P. Trumbull. On the other hand, several defense attorneys did not think that $\S 1983$ suits caused or contributed to any changes in police practices. D. Berkeley, D. Chao, D. George.

174. Thirteen attorneys said that the municipalities that had made payments did not pressure their police departments to minimize police misconduct. D. Arcadia, D. Chao, D. Delmonico, D. Dwight, D. England, D. George, D. Kavanaugh, D. Kaysey, D. Leon, D. Moore, D. Naples, M. Blake, M. Edwards. Only one attorney said that some pressure might exist. D. Pierson.

175. See p. 789 supra.

176. See p. 811 supra.

177. P. Sherman, D. Chao, D. Clark, D. Dwight.

178. Turpin v. Mailet, 579 F.2d 152, 155 (2d Cir.), vacated and remanded sub nom. City of W. Haven v. Turpin, 47 U.S.L.W. 3360 (U.S. Nov. 28, 1978) (en banc).

179. Weinstein, Long History of Police Misconduct in Bridgeport, C.C.L.U. News, June 1978, at 2, col. 1 . 
In some instances, even if municipal officials had tried, they probably would have been powerless to effect changes in the police department. For example, some attorneys pointed to the fact that one police chief had established a political base independent of the mayor, thus insulating the police department from outside influence. ${ }^{180}$ In that city even the corporation counsel, ostensibly under the mayor's control, was directed in the defense of police misconduct suits by the police chief. ${ }^{181}$ In other instances, line officers have become more aggressive in protecting their own interests. ${ }^{182}$ Police unions have taken increasingly militant positions demanding protection of individual officers against the threat of civil suits. ${ }^{183}$ In view of the growing strength of the unions, ${ }^{184}$ it has become politically expedient for the municipality to accede to the demand for guaranteed indemnification against any loss incurred in a suit. ${ }^{185}$

Section 1983 suits thus had little impact on the police departments in the Project sample. If deterrence is predicated on the municipality taking action against the police department, then there was no example of deterrence in the Project sample.

\section{Conclusion}

The Project's research documents that suits in the sample brought under 42 U.S.C. $\$ 1983$ did not compensate plaintiffs for violations of their constitutional rights or deter police officers from engaging in proscribed behavior. Plaintiffs who sued the police had to overcome substantial impediments in order to receive redress, as the small number of successful plaintiffs indicates. The jurors disfavored plaintiffs who were nonwhite or nonmiddle-class, or who had had previous brushes with the law. The jurors favored police officers because they were viewed as respectable people performing a difficult and necessary job. These biases were enhanced by the juror selection process.

Both the individual defendants and the police departments were insulated from the financial burden consequent to a section 1983 suit.

180. P. Sherman, D. Delmonico, D. Oxford.

181. P. Sherman, D. Delmonico, D. Oxford.

182. D. Delmonico, M. Edwards. Two United States District Judges, J. Mory, J. York, and two police chiefs, O. Mara, O. Pepe, emphasized the power of police unions.

183. D. Clark, O. Mara; see O. Pepe (union contract limits effects of $\S 1983$ suits on officers' careers); J. York (municipalities' supervisory power restricted because unions do "too much managing").

184. Comment, Reviewing Civilian Complaints of Police Misconduct-Some Answers and More Questions, 48 TEMP. L.Q. 89, 122 (1974); see Juris, The Implications of Police Unionism, 6 LAw \& Soc. REv. 231 (1971).

185. Two attorneys mentioned the practical political necessity for indemnification. See D. Delmonico ("From a political point of view, we can't have police officers pay."); M. Edwards (same). 
Supervisory officials were never found liable; line officers were indemnified for damage awards and settlement costs. The costs of the suits were not high, and were often hidden, so that little incentive was given the municipality to discipline the police. Political exigencies also inhibited attempts by the municipality to control its police department's behavior. Thus, if deterrence depends upon the imposition of financial loss on the individual police officers, or upon the imposition by municipalities of sanctions against the police department, these suits did not deter police misconduct.

If the Project findings show jury bias, they presage no simple solution. However, the data do suggest several changes that would not affect preexisting biases of jurors, but nevertheless would eliminate several means by which these prejudices are enhanced. First, at the very minimum, potential jurors should not be selected from voter registration records alone. ${ }^{186}$ Lists of potential jurors should be augmented by names from other sources that are more representative of the total qualified population in the district. ${ }^{187}$ With greater numbers of blacks appearing on jury panels, more blacks might remain after peremptory challenges to serve on juries. ${ }^{188}$ The addition of black jurors would promote broader deliberation and perhaps counteract biases of other jurors. ${ }^{189}$ Second, jurors who have deliberated on one police misconduct case should not be allowed to sit on another during their term of service. The exclusion of repeat jurors would eliminate a class of jurors who, as the data have shown, consistently favored the defendant. ${ }^{100}$ Third, the good faith defense should be eliminated from police misconduct suits. ${ }^{181}$ To the extent that the doctrine affects jury

186. Each United States district court must adopt a plan to select juries in a random, nondiscriminatory manner from a fair cross section of the community. See 28 U.S.C. $\$ \S 1861-1863$ (1976). The statute explicitly permits the addition of names from sources other than voter registration lists in order to eliminate discrimination and to obtain a fair cross section of the community. Id. $\$ 1863(\mathrm{~b})(2)$.

187. A majority of the conferees in a recent study of juries recommended making juries more representative by augmenting juror lists with names from driver's license records, welfare rolls, telephone directories, or other such sources. AMERICAN JURY SYSTEM, supra note 7 , at 22.

188. In districts with relatively small populations of blacks, augmentation of jury lists, by itself, will not guarantee the inclusion of more blacks on juries. In the District of Connecticut, for example, blacks comprise about six percent of the population. See notes 141 \& 142 supra. If a completely random sample were taken from the District's population, the statistically expected number of blacks on a jury panel of 30 would be fewer than two. An attorney who desired to exclude blacks from a jury, see p. 807 supra, could still do so, even though he might be forced to expend more of his peremptory challenges.

189. See p. 807 supra.

190. See pp. 808.09 supra.

191. The good faith defense was imported from the common law into $\$ 1983$ by judicial decision. Pierson v. Ray, 386 U.S. 547, 557 (1967); see note 11 supra. The defense can be eliminated by judicial decision as well. 
verdicts, it is an added protection for the police officer who already benefits from the biases of jurors. ${ }^{192}$

Two further changes should be instituted in order to make section 1983 suits more effective. First, municipalities should be made strictly liable for the unconstitutional acts of their police officers; second, the individual officers should pay, without indemnification, for any punitive damages awarded against them. Holding municipalities strictly liable for the actions of their police officers would elevate the current practice of indemnification to a legal standard. ${ }^{103}$ The municipality's liability would be limited to those instances in which the officer's action is performed under color of state law, as prescribed by section 1983 itself. ${ }^{194}$

It is unfair and impractical to demand that before a municipality is held liable, the plaintiff must show a causal link between a municipal policy or custom and the act of the individual police officer. ${ }^{195}$ The

192. Elimination of the good faith defense does not deny the defendant an opportunity to prove the reasonableness of his actions. Whether plaintiffs allege illegal searches, false arrests, or uses of excessive force, the defendants' conduct is judged by a standard of reasonableness. For example, to prove that he was falsely arrested, the plaintiff must show that, under the circumstances, a reasonably prudent officer did not have probable cause to believe that the plaintiff committed a crime. See Henry v. United States, 361 U.S. 98, $102(1959)$ (probable cause to arrest exists if officer reasonably believes crime has been committed); Martin v. Duffie, 463 F.2d 464, 468 (10th Cir. 1972) (plaintiff has risk of nonpersuasion in $\$ 1983$ suit on issue of lack of probable cause to arrest).

193. See pp. 810-11 supra.

194. The "under color of" provision in $\$ 1983$ was defined by the Supreme Court as “[m]isuse of power, possessed by virtue of state law and made possible only because the wrongdoer is clothed with the authority of state law." Monroe v. Pape, 365 U.S. 167, 184 (1961), overruled in part, Monell v. Department of Social Servs., 436 U.S. 658 (1978) (quoting United States v. Classic, 313 U.S. 299, 326 (1941)). Thus, for example, the municipality is not liable for the injuries inflicted by an unarmed, off-duty, out-ofuniform police officer initiating a barroom brawl without pretense of authority. $C f$. Stengel v. Belcher, 522 F.2d 438, 441 (6th Cir. 1975), cert. dismissed, 429 U.S. 118 (1976) (liability under $\S 1983$ of off-duty police officer for shooting plaintiffs with service revolver while intervening in barroom dispute "pursuant to a duty imposed by police department regulations"); Payne v. Government of Dist. of Columbia, 559 F.2d 809, 824 (D.C. Cir. 1977) (Tamm, J., concurring) (liability under $\S 1983$ of off-duty, out-of-uniform police officer for shooting while "attempting to investigate the possible theft of certain items from his car").

195. For discussion of the applicable law, see note 20 supra. In this respect a police misconduct suit is analogous to a products liability action. The requirement that a plaintiff plead and prove an express or implied warranty before the manufacturer is held liable has been rejected, in favor of a strict liability standard. The plaintiff must show only that he was injured while using a product as it was intended to be used. Greenman v. Yuba Power Prods., Inc., 59 Cal. 2d 57, 377 P.2d 897, 27 Cal. Rptr. 697 (1963). Just as the plaintiff's ability to prove reliance on a warranty, "an expensive, time-consuming, and wasteful process," Prosser, The Assault Upon the Citadel, 69 YALE L.J. 1099, 1124 (1960), should not control a products liability case, an individual plaintiff's ability to prove a causal link between a municipal custom and the unconstitutional act of a police officer should not control a police misconduct case. The goals of a strict liability standard in products liability cases are (1) to minimize danger to consumers, (2) to place the 
municipalities have the knowledge of police practices and the power to change department policy; they should therefore be made responsible to remedy the illegal activities of their employees. ${ }^{196}$ Furthermore, the data have shown that even in instances in which the municipalities themselves were arguably blameless, the individual police officers were indemnified for their legal expenses as well as for settlement costs and for damage awards. ${ }^{197}$ This policy insulates police officers from the consequences of misconduct suits, and dictates that responsibility for the unconstitutional actions of police employees lies with municipalities.

The adoption of a standard of strict liability will ensure that damages awarded to successful plaintiffs will be paid by "deep pocket" defendants. ${ }^{198}$ The costs of police misconduct thus will be borne by the municipalities' citizens who are the beneficiaries of police protection. ${ }^{199}$ Moreover, because juries would be aware of the municipal "deep pockets," reluctance to find liability or to award fully compensatory damages against individual police officers might diminish. More, and

burden of loss on the manufacturer, who can best minimize the danger, and (3) to distribute the losses equitably among the consuming public, as a cost of doing business. 2 F. HARPER \& F. JAMES, The LAW OF TorTs $\$ 28.16$, at 1571 (1956). The goals of a strict liability standard in police misconduct cases are comparable: (1) to minimize unconstitutional acts, (2) to place costs on the municipality, which can deter unconstitutional acts, and (3) to distribute the losses equitably among the citizens of the municipality, who are the beneficiaries of police protection.

196. Turpin v. Mailet, 579 F.2d 152, 165 (2d Cir.), vacated and remanded sub nom. City of TW. Haven v. Turpin, 47 U.S.L.W. 3360 (U.S. Nov. 28, 1978) (en banc) (municipality arguably in best position to reduce misconduct); Hundt, supra note 5 , at $782-83$ (deterrence enhanced because municipality directs employees to adhere to constitutional standards and acts to diminish future violations); Newman, supra note 3, at 457 (municipal liability provides incentive to monitor performance of police, insist on observance of constitutional standards, and exercise internal discipline). See also K. Davis, Administrative LAw Treatise $\$ 25.17$, at 863-64 (Supp. 1970) (limits on effectiveness of loss distributing function of tort law as applied to public entities).

197. See p. 811 supra.

198. See G. Calabresi, The Costs of Accibents 21 (student ed. 1970) ("deep pocket" is means of risk distribution that places losses on party best able to pay).

199. See Turpin v. Mailet, 579 F.2d 152, 165 (2d Cir.), vacated and remanded sub nom. City of W. Haven v. Turpin, 47 U.S.L.W. 3360 (U.S. Nov. 28, 1978) (en banc) (municipality well-suited to spread cost of compensating victims); Hundt, supra note 5 , at 783 (Fourteenth Amendment rights are "public rights" to be supported by public). Judges have expressed concern that the imposition of municipal liability will raid municipal treasuries. Monell v. Department of Social Servs., 436 U.S. 658, 724 (1978) (Rehnquist, J., dissenting) (leaves "limited treasuries" unprotected); Turpin v. Mailet, 579 F.2d 152, 179 (2d Cir.), vacated and remanded sub nom. City of W. Haven v. Turpin, 47 U.S.L.W. 3360 (U.S. Nov. 28, 1978) (Van Graafeiland, J., dissenting) (exposure to "incalculable liability"). Judge Van Graafeiland termed it a "painful likelihood" that municipal liability will "act as a catalyst in the exacerbation of social friction." Id. at 182. If municipalities are not held liable, however, the social and economic burden of police misconduct is borne by the uncompensated victims. The cost does not disappear merely because recovery is not allowed. 
higher, jury awards should result..00 These awards would provide greater incentive to municipalities to discipline their police officers and to reduce future misconduct. The demonstrated disinclination of municipalities to promulgate corrective policies can be changed only if municipalities are forced to protect their own financial interests by preventing the unconstitutional behavior of their employees.

Municipalities, however, should not be liable for punitive damages awarded against individual officers. ${ }^{201}$ In those egregious cases that prompt jurors to award punitive damages, justice requires that they be paid solely by the individual officer at fault. In contrast to current practice, municipalities should not be allowed to indemnify their officers for such awards. ${ }^{202}$ The possibility of personal financial loss may help deter future misconduct. ${ }^{203}$

This Project has demonstrated the severe shortcomings of section 1983 suits when used as a remedy for police misconduct. It is hoped that institution of the proposed changes will enable section 1983 to provide a more effective means of redress. However, because the deficiencies of police misconduct suits-jury bias, and an inability to influence police behavior-are so fundamental, it would be naive to assume that relatively minor modifications will produce significant results. These proposals constitute a first step toward affording an adequate remedy for police misconduct. At best, their adoption may stimulate other, more effective innovations.

200. See Newman, stıpra note 3 , at $456-57$ (ignorant of indemnification, juries tend to find for defendants or award modest damages); cf. W. Prosser, Handbook of THE LAw of ToRTs 549 (4th ed. 1971) (juries tend to return more frequent or larger verdicts against defendants with liability insurance).

201. Federal common law allows recovery of punitive damages in civil rights actions. See, e.g., Caperci v. Huntoon, 397 F.2d 799 (1st Cir.), cert. denied, 393 U.S. 940 (1968) (punitive damages allowed under $\$ 1983$ for outrageous invasion of privacy in illegal search); Basista v. Weir, 340 F.2d 74, $87-88$ (3d Cir. 1965) (dicta recognizing possibility of punitive damages under $\$ 1983$, new trial ordered).

202. See pp. 810-11 supra.

203. See G. CALABRESI, supra note 198, at 269-70 (sometimes noninsurable penalty most effective deterrent). One fear that has been raised concerning municipal liability is that employees will become more inclined to commit unconstitutional acts if they are not subject to personal liability. See Hundt, supra note 5 , at 783. 
Appendix 1: AtToRney Questionnaire

\section{Questions Asked All Attorneys:}

1. Name

2. Size of office: $2-3$ $4-9$ 10 or more

3. Years practicing law:

4. Please describe the type of practice that you have.

5. Have you ever been involved in a $\$ 1983$ suit other than the ones mentioned in our letter? How many? If yes, have you represented the plaintiff/defendant in all these suits? If you have not always represented the plaintiff/defendant, how were you involved?

6. What factors are most important in determining the outcome of your cases?

7. Do you settle these suits out of court more often or less often than you do other claims against the municipality? Why?

8. What were the differences between the cases that you took to trial and those you settled out of court?

9. Are most juries biased in favor of or against one side or the other in $\S 1983$ suits? Do you think the biases are for, against, or both? (Which side?) Why?

10. What effect does this bias have on your strategy during either negotiation or trial?

11. Do you have a better chance for "success" with a bench trial or a jury trial? Why?

12. Do judges treat these cases differently from other cases? Are judges neutral in their handling of these suits? If not, which side do they favor or oppose? How do they show their biases?

13. What, if any, procedural issues have a significant impact on the outcome of the suit?

14. We have not read the depositions in these cases because they are not part of the public record. Could you describe what information is available in depositions that is not available through other means of discovery?

15. Is the good faith defense important or unimportant in these suits? Why?

16. Do you think the good faith defense affects the jury's verdict?

17. What do you think the jury understands the good faith defense to be?

18. How does the good faith defense affect your overall trial or negotiation strategy?

19. Do you believe that $\S 1983$ suits deter police misconduct? Why?

20. Do you know from personal experience of any changes in police practices because of $\S 1983$ suits? What were they?

21. Do you believe that the level of police misconduct in Connecticut has increased, decreased, or stayed the same since 1970? Why?

22. Why has the number of $\S 1983$ police misconduct suits in this area increased over the last ten years?

23. Have you ever appealed any $\S 1983$ suits?

24. What types of cases do you appeal? 
25. Were any of your appeals carried through to appellate decisions? If yes, what was the outcome? If no, why not? If you settled, what were the settlements?

26. What statutory reforms of $\S 1983$ and/or changes in its judicial interpretation would you suggest? Why?

27. In order to understand fully these $\$ 1983$ misconduct suits, what did we fail to ask that we should have asked?

\section{Questions Asked Plaintiffs' Attorneys:}

28. Have you been denied access to any documents that you felt were essential to your case?

29. Have you ever brought a $\$ 1983$ suit in state court? Why, or why not?

30. What are the advantages and disadvantages of suing the police under $\S 1983$ as opposed to a common law tort action?

31. Have you ever brought a common law tort claim against the police other than a pendent claim?

32. How do you calculate the dollar amount to be sought for damages?

33. In your argument to the jury on damages, do you distinguish between relief for the violations of the plaintiff's constitutional rights and his other injuries and losses?

34. Given two plaintiffs, with similar physical injuries, would you rather sue the owner of a store for his alleged negligence in causing the plaintiff's injuries or would you rather sue a police officer who allegedly had intentionally injured the plaintiff? Why?

In the police case, would it make the plaintiff's claim more or less valuable if he also suffered intangible losses?

35. Who do you think should be liable for the plaintiff's damages in $\S 1983$ police misconduct cases?

36. Are insurance companies involved in these suits? How?

37. Are the plaintiffs involved during the preparation of $\S 198$ f cases? How?

38. How did your clients find out about you?

39. Do you undertake these suits on a contingent fee basis? If not, what type of compensation arrangement do you have?

40. Do you think the recent change in the civil rights statute, which allows attorneys' fees to the successful party, will affect your handling of these suits?

41. In comparison with your other legal work, are $\$ 1983$ suits of above average, average, or below average remuneration?

42. What motivates you to bring these suits?

\section{Questions Asked Defendants' Attorneys:}

43. In these suits were you employed as Corporation Counsel, as a private attorney paid by the municipality, as a private attorney paid by the police officer or in another capacity?

44. What documents are the subject of most dispute during the discovery process? Why? 
45. What would be the impact on these cases of giving the plaintiffs access to reports of internal police department disciplinary investigations?

46. Are the defendants involved during preparation of these suits? Why?

47. Are insurance companies involved in these suits? Why?

48. Does the municipality always indemnify the individual defendants?

49. Is the municipality ever dismissed from the suit in exchange for its agreement to pay any damages awarded to the plaintiff?

50. When the municipality indemnifies individual police officers, does the municipality then put pressure on the police department to minimize police misconduct and resultant $\S 1983$ suits?

51. Do you perceive your role more as a defender of the individual police officers or as a protector of the public treasury?

52. Do you think the recent change in the civil rights statutes, which allows attorneys' fees to the successful party, will affect your handling of these suits?

53. What percentage of these suits do you think are frivolous?

54. Do you characterize these cases as attorneys' cases or plaintiffs' cases?

\section{APPENDIX 2: JUROR QUESTIONNAIRE}

1. What was the outcome of the trial?

A. The police officer won.

B. The plaintiff won.

C. Some plaintiffs won and some police officers won.

2. If money was awarded to the plaintiff, how much was awarded?

Plaintiff \#1

If more than one plaintiff:

Plaintiff \#2 Plaintiff \#3

If you do not remember how much was awarded to each individual plaintiff, what was the total amount of money awarded to the plaintiffs?

A. S_ B. I do not remember.

3. Which of the following actions were any of the police officers accused of?

A. Shooting

B. Unlawful arrest

C. Unlawful search

D. Excessive force/police brutality

E. Other (please specify)

4. What was your reaction to the plaintiff's attorney?

A. Strongly liked

B. Liked

C. Neutral

D. Disliked

E. Strongly disliked 
If more than one attorney:
Attorney \#2:
Attorney \#3:
Attorney \#4:
A.
B.
C. -D. -E.
-A. -B. - - C.
D. E.
D. -E.

5. What was your reaction to the police officer's attorney?

A. Strongly liked

B. Liked

C. Neutral

D. Disliked

E. Strongly disliked

If more than one attorney:
Attorney \#2:
Attorney \#3:
Attorney \#4:
A.
A. B.
A.
B. C.
D. - E.
C. D. -E.

id the plaintiff's lifestyle affect your verdict?

6. Did the plaintiff's lifestyle affect your verdict?
A. Yes-it greatly affected my verdict.

B. Yes-it affected my verdict some.

C. No-it did not affect my verdict.

If yes, in what way was your verdict affected?

A. In favor of the plaintiff

B. Against the plaintiff

If yes, please write in the space below what it was about the plaintiff's lifestyle that affected your verdict.

7. Did the plaintiff have a criminal record?

A. Yes

B. No

C. I was never told.

D. I do not remember.

If yes, how did the plaintiff's criminal record affect your verdict?

A. Strongly against the plaintiff

B. Against the plaintiff

C. No effect

8. Did the fact that the defendant was a police officer affect your verdict?

A. Yes-it greatly affected my verdict.

B. Yes-it affected my verdict some.

C. No-it did not affect my verdict.

If yes, in what way was your verdict affected?

A. In favor of the police officer

B. Against the police officer

9. Did the police officer think his actions were reasonable?
A. Yes
B. No

Regardless of what the police officer thought, did you think his actions were reasonable?
A. Yes
B. No 
10. People sometimes feel that a plaintiff's rights were violated but that other persons, in addition to a police officer, should have been sued. Did you feel this way about this trial?
A. Yes
B. No

If yes, who else should have been sued?

A. City

B. Superior officers

C. Other police officers

D. Other (please specify)

If yes, please write in the space below the reason why you thought that someone else should have been sued.

11. Did the judge properly conduct the trial? A. Yes B. No

If no, please write in the space below what he did that was improper.

12. Did the police officer's ability to pay any money awarded to the plaintiff affect your verdict?
A. Yes
B. No

If yes, how did it affect your verdict?

A. I found the police officer not liable.

B. I awarded more money than I would have otherwise.

C. I awarded less money than I would have otherwise.

13. There is a doctrine, sometimes called the good faith defense, which says that if a police officer believed, in good faith, that his conduct was lawful and if his belief was reasonable, then he is not liable for his actions.

(a) Was this doctrine mentioned by the judge?

A. Yes (If yes, please go to question \#13 b.)

B. No (If no, please go to question \#14.)

C. I do not remember. (If you do not remember, please go to question \#14.)

(b) Did you feel that this doctrine was adequately explained by the judge?
A. Yes
B. No

(c) Did this doctrine affect your verdict?

-A. Yes (If yes, please go to question \#13 d.)

B. No (If no, please go to question \#14.)

(d) How did this doctrine affect your verdict?

A. Strongly in favor of the police officer

B. In favor of the police officer

C. Against the police officer

D. Strongly against the police officer

(e) Please write in the space below the reason why the doctrine affected your verdict this way.

14. Did you think that a verdict against the police officer would affect the police department's ability to control crime?
A. Yes
B. No 
If yes, the police department's job would be made

A. Much more difficult

B. More difficult

C. Easier

D. Much easier

15. Did you think that a verdict against the police officer would serve as a warning to other police officers not to do similar acts in the future? A. Yes B. B. No

If yes, did you think such a result was desirable?

A. Yes B. No

16. Did you think that the police officer would not have to pay any money awarded to the plaintiff because someone else would pay the money for him?
A. Yes
B. No

If yes, who did you think would pay the money for him?

A. An insurance company

B. The city

C. Superior officers

D. Other (please specify)

17. If you awarded damages to the plaintiff, please describe in the space below the losses and injuries for which you gave the plaintiff money.

18. Was reaching your verdict easy or difficult?
A. Easy
$B$. Difficult

Please write in the space below the reason why it was easy or difficult.

19. What was your age at the time of the trial?

A. $18-30$

B. $31-40$

C. $41-50$

D. $51-60$

E. $61-70$

F. Over 70

20. What is your sex?

_. Male

B. Female

21. What was your educational level at the time of the trial?

A. High school not completed

B. High school completed

C. Trade school

D. Some college

E. College completed

F. Post-graduate study

22. If you would like to add anything or explain your answers, we encourage you to do so in the space below. 